\title{
Mluvit, či nemluvit? Participace na výukové komunikaci očima vokálních a tichých žáků a jejich učitelek ${ }^{1}$
}

\author{
Klára Šed'ová \\ Masarykova univerzita, Filozofická fakulta, Ústav pedagogických věd
}

\begin{abstract}
Abstrakt: Tato studie vychází ze známého faktu, že různí žáci ve třídě participují odlišnou měrou na výukové komunikaci. Někteří žáci jsou velmi vokální, často a ochotně si berou slovo, jiní zůstávají tiší. Ačkoliv existuje řada studií, které se žákovskými participačními vzorci zabývají, jen velmi zřídka je zkoumána vnitřní perspektiva žáků a jejich pohled na věc. Realizovali jsme terénní etnografické šetření ve výuce českého jazyka a literatury ve čtyřech 9. třídách základní školy. Pořizovali jsme videonahrávky výuky a také rozhovory se žáky a jejich učitelkami. $V$ této studii vytěžujeme data $z$ rozhovorů s cílem porozumět participačním vzorcům ve sledovaných tř́dách a zachytit významy, které jsou participaci připisovány ze strany žáků i jejich učitelů. Soustředíme se přitom na zachycení rozdílů mezi žáky vokálními a tichými a mezi žáky školsky úspěšnými a neúspěšnými. Naše analýza ukazuje, že participační chování žáků silně souvisí s tím, jaké př́ležitosti k učení tito žáci získávají, dále jak kompetentní a inteligentní se jeví sami sobě i svým vyučujícím. Z tohoto hlediska existuje ve trí́dách silně znevýhodněná skupina, a to jsou tiší neúspěšní žáci.
\end{abstract}

Kličová slova: výuková komunikace, žákovská participace, školní úspěšnost, rozdíly mezi žáky, př́ležitosti k učení

\section{To Speak, or Not to Speak? How Vocal and Silent Students and Their Teachers See Participation in Classroom Discourse}

Abstract: This study is based on the well-known fact that different students in the same classroom participate differently in classroom discourse. Some students are vocal, often and willingly raise their voice, whereas others remain silent. Although many studies are dealing with student participation patterns, the inner perspective of students and their point of view are explored very rarely. We conducted an ethnographic inquiry in language arts lessons in four ninth grade classes. We took video recordings of lessons as well as interviews with students and their teachers. In this study, we analyse interview data with the aim to understand classroom discourse participation patterns and to identify meanings of these patterns as perceived by students and their teachers. We focus on differences between vocal and silent students as well as differences between high-achieving and low-achieving students. Our analysis shows that student participation behaviour is linked to learning opportunities that students gain. Also, student participation behaviour has a noticeable impact on how competent and intelligent appear to themselves and their teachers. Concerning this, silent low-achieving students are heavily disadvantaged.

Keywords: classroom discourse, student participation, student achievement, learning opportunities

1 Text vznikl s podporou grantu GA ČR „Vztah mezi charakteristikami výukové komunikace a vzdělávacími výsledky žákư“ (GA17-03643S).

(c) 2018 The Author. This is an open-access article distributed under the terms of the Creative Commons Attribution License (http://creativecommons.org/licenses/by/4.0), which permits unrestricted use, distribution, and reproduction in any medium, provided the original author and source are credited. 
66 V posledních dekádách se zdůrazňuje centrální role řeči a komunikace ve vztahu k učení a vytváření znalostí ve tř́idě. Předpokládá se, že se žáci učí skrze řeč a jejich vzdělávací výsledky lze do značné míry připsat kvalitě výukové komunikace (např. Mercer \& Littleton, 2007; Resnick, Asterhan, \& Clarke, 2017). Vedle rozvinuté teoretické základny (srov. Šed'ová, 2016) existují rovněž empirické doklady o tom, že zapojení žáků do komunikace pozitivně ovlivňuje učení. Máme $\mathrm{k}$ dispozici studie, které tento fakt prokazují na úrovni školní třídy - ve třídách, v nichž je výuka pojata dialogicky a žáci více hovoří, jsou jejich výsledky lepší než ve třídách, v nichž hovoří především učitel a míra zapojení žáků do komunikace je nižší (kupř. Applebee et al., 2003; O’Connor, Michaels, \& Chapin, 2015; Alexander, 2018; Muhonen et al., 2018). Ve všech těchto studiích byly měřeny různé charakteristiky výukové komunikace a dávány do souvislosti s výsledky žáků² agregovanými na úrovni tř́idy.

Vedle toho existují též studie, které se pozitivní vztah mezi participací v komunikaci a učením snaží prokázat na úrovni jednotlivých žáků. To znamená, že pracují s předpokladem, že efekty výukové komunikace mohou být pro jednotlivé žáky ve třídě rưzné, nebot' tito žáci do komunikace rozdílným zpưsobem vstupuji a podílejí se na ní. Studie tohoto typu provedli Webb et al. (2014) a Ingová et al. (2015). Tito autoři realizovali výzkum ve výuce matematiky na vzorku 111 žáků. Pomocí videokamery byly snímány veškeré promluvy žáků a byly kódovány podle toho, zda žáci referují o vlastních myšlenkách, anebo komentují myšlenky druhých, a dále podle míry konceptuální rozpracovanosti. Žákovské výsledky byly měřeny pomocí standardizovaných matematických testů. Analýza prokázala pozitivní souvislost mezi tím, jak se ten který žák verbálně zapojuje, a jeho výsledky $v$ testech. Šed’ová et al. (2019) realizovali šetření na vzorku 639 žáků ve výuce českého jazyka a literatury. Měřili délku promluv jednotlivých žáků během výuky a také počet propracovaných promluv s argumentací, které jednotliví žáci vyslovili. Žákovské výsledky byly měřeny prostřednictvím testu čtenářské gramotnosti vytvořeného a distribuovaného Českou školní inspekcí. Výsledky ukázaly, že pro žáky je do jisté míry zvýhodňující, nacházejí-li se ve třídě, v niž je větší množství žákovské řeči. Mnohem silnější se však ukázala individuální souvislost. Čím více žák hovoří a argumentuje, tím lepší má výsledky. ${ }^{3}$

Z uvedeného vyplývá, že velmi záleží na tom, jak jsou př́ležitosti promluvit distribuovány mezi jednotlivými žáky ve tříě, nebot' čím více konkrétní žák mluví, tím více je zvýhodněn. Proto je zásadní zkoumat, jak a proč jsou v běžné výuce konstruovány participační vzorce - co rozhoduje o tom, který žák bude hovořit často a dlouze, a který žák naopak zůstane pasivní.

2 Nejčastěji šlo o testy, alternativně byly jako ukazatele výsledků užívány též známky či výkony žáků v produktivních úlohách.

3 Výše uvedené studie měly korelační design. Kauzalita spojení mezi řečí a výsledky je tudíž neprůkazná. Velmi pravděpodobně jde v obou směrech: čím více žáci hovoří, tím více se učí a zároveň čím více jsou žáci naučeni, tím více hovoří. 


\section{Rozdílné participační vzorce}

Řada výzkumů poukázala na to, že se žáci do výukové komunikace nezapojují ve srovnatelné míře. Tento typ nálezů odstartovala klasická studie Brophyho a Gooda (1970) a základní zprávu o tom, že kvantita i kvalita verbálních interakcí s učitelem jsou v rámci jedné třídy velmi variabilní, potvrzují mnohá novější šetření (např. Myhill, 2002; Black, 2004; Jurik, Gröschner, \& Seidel, 2013; Clarke, 2015; Helgevold, 2016; v českém prostředí Zormanová, 2009; Šed’ová, Sucháček, \& Majcík, 2015). Podle Blackové (2004) lze přitom říci, že jednotliví žáci mají tendenci se zapojovat určitým stabilizovaným způsobem, mají tedy specifické participační vzorce, jimiž se mezi sebou navzájem liší.

Kovalainenová a Kumpulainenová (2007) na základě etnografického pozorování $\checkmark$ jedné finské třídě uvádějí, že z hlediska participace lze rozlišit následující typy žáků: 1) Vokální participanti: Charakteristická je pro ně vysoká míra participace. Zapojují se jak prostřednictvím odpovědí na otázky učitele, tak formou vlastních iniciací. Oslovují učitele i spolužáky. 2) Responzivní participanti: Charakteristická je pro ně střední míra participace. Orientují se na interakce s učitelem, zapojují se formou odpovídání na jeho otázky. 3) Bilaterální participanti: Charakteristická je pro ně střední míra participace. Odpovídají na dotazy i sami iniciují komunikaci, orientují se na učitele i na spolužáky. 4) Tiší participanti: Charakteristická je pro ně nízká míra participace. Pokud se zapojí, tak výhradně odpovídají na otázky učitele.

Podle Blackové (2004) existují rozdíly mezi žáky také $v$ tom, jak produktivní je jejich participace. Při neproduktivní participaci jsou žákovské promluvy krátké a rutinní, nevyžadují velké kognitivní úsilí, cílem žáků je $v$ prvé řadě vyhovět požadavkům učitele. Naopak produktivní participace znamená, že žákovské promluvy odrážejí kognitivní procesy směřující $k$ vytváření nového vědění. Jsou rozvité, obsahují argumentaci a zdůvodňování. Žáci se tak mezi sebou liší nejen četností své participace, ale též kvalitou svých příspěvků (Black, 2004).

\section{Proč žáci participují různě?}

Nabízí se otázka, co stojí za různou podobou žákovské participace. Existují studie, které postulují, že způsob, jakým se žák zapojuje do výukové komunikace, je silně ovlivněn tím, jak se $\mathrm{k}$ němu chová učitel a jaké přiležitosti $\mathrm{k}$ participaci pro něj vytváří (Brophy \& Good, 1970; Black, 2004; Black, 2007; Šed’ová \& Šalamounová, 2016; Snell \& Lefstein, 2018). Blacková (2004, 2007) tvrdí, že participační vzorce jsou odvislé od toho, že se učitelé chovají k žákům odlišně podle svých akademických očekávání, která k nim vztahují. Žáky, které považují za schopné, mají tendenci vybízet k produktivní participaci, zatímco žákům, o jejichž schopnostech mají nižší mínění, nabízejí spiše př́ležitosti k participaci neproduktivní (např. jim kladou jednoduché pamětní otázky). 
Jiní autoři vidí příčinu nerovností v participačních vzorcích (viz Black, 2004), zejména v charakteristikách žáků (Seidel, 2006; Jurik et al., 2013). Řada studií prokázala souvislost mezi mírou participace a školní úspěšností žáků - žáci s dobrým prospěchem participují více než žáci se slabým prospěchem (Myhill, 2002; Kelly, 2008; Jurik et al., 2013; Šed'ová et al., 2015). Některé výzkumy dále spojují míru participace se socioekonomickým zázemím žáků. Žáci z rodin s vyšším socioekonomickým statusem participují více (Kelly, 2008; Black, 2007). Komplexním způsobem zkoumali problematiku Juriková et al. (2013), kteří realizovali šetření na vzorku 1378 patnáctiletých žáků v hodinách fyziky. Míru jejich participace dávali do souvislosti s jejich charakteristikami zjišt’ovanými prostřednictvím dotazníků a psychologických testů. Podle jejich nálezů se do komunikace zapojují především žáci kognitivně schopní, motivovaní a s pozitivním postojem $\mathrm{k}$ předmětu.

Řada studií pracuje s konceptem žákovské identity (Black, 2004; Triplett, 2007; Hall et al., 2010; Snell \& Lefstein, 2018). Slovy Browna (2004) jde o identitu diskurzivní, tedy o pozici jednotlivce $v$ toku interakcí. Termín identita je $v$ těchto studiích použiván ambivalentně, jednak ve smyslu autentického žákovského sebepojetí, které předjímá ochotu zapojit se do komunikace, jednak ve smyslu připsané identity, tedy očekávání, která k žákovi vztahují učitel a spolužáci. Jak záměry a osobnostní výbava žáka, tak očekávání a akce jeho okolí tvoří determinanty jeho zapojení do komunikace. Kumpulainenová a Rajala (2017) realizovali dlouhodobé pozorování ve výuce přírodovědy. Ukázali, že mezi sebou souvisí participační chování žáků a jejich identita. Ve chvíli, kdy se změnilo participační chování žáků - např. obvykle vyrušující chlapec požádal o možnost ř́idit diskusi a bylo mu to dovoleno -, došlo také $k$ identitní změně.

Je poněkud překvapivé, že ačkoli jsou žákovské participační vzorce zkoumány vcelku soustavně (viz studie citované výše), realizované výzkumy se př́liš nesnaží postihnout subjektivní žákovskou perspektivu. Realizované studie jsou založeny nejčastěji na pozorování interakcí ve výuce a na zjišt’ování vlastností žáků pomocí dotazníků a testů. Šetření, v nichž by se výzkumníci žáků prostě dotázali, jaké mají důvody se zapojit nebo nezapojit do výukové komunikace, jsou velmi zř́́dkavé. Výjimku představují studie realizované Clarkovou (Clarke, 2015; Clarke et al., 2016). Ta dlouhodobě sledovala hodiny biologie ve třech třídách vyučovaných jednou učitelkou. Z těchto tří tříd rekrutovala vzorek 16 žáků, kteří byli dvakrát interviewováni. Vzorek si rozdělila do dvou částí, na žáky, kteří se zapojují hojně, a žáky, kteří se zapojují málo. Ve slovníku Kovalainenové a Kumpulainenové (2007) šlo o žáky vokální a tiché. Zjistila, že žáci silně spojují participaci se znalostmi. Nejčastěji byly znalosti líčeny jako podmínka participace - podle žáků se může zapojit ten, kdo zná správnou odpověd’. Když autorka porovnala výpovědi vokálních a tichých žáků, zjistila, že u vokálních se objevuje rovněž pojetí znalosti jako výsledku participace to znamená, žáci popisovali situace, v nichž se díky svému zapojení do komunikace naučili něco nového, co předtím neuměli. Tento pohled na věc u tichých zcela absentoval. Clarková (2015) z toho vyvozuje, že specifikem vokálních žáků je fakt, že jsou schopni překročit předpoklad, že je třeba znát správnou odpověd', aby se člověk 
mohl zapojit. Navazující analýza (Clarke et al., 2016) potom ukázala, že vokální žáci popisují svoji participaci jako důsledek vlastního rozhodnutí, zatímco tiší žáci více zdůrazňují vnější situační faktory (chování učitele či spolužáků, kurikulum, sociální normy). Clarková et al. (tamtéž) zdůrazňují, že participační chování má obě složky - jednak je žák do určité míry agentní ve smyslu vlastního záměru participovat, jednak mu daná situace do určité míry agentnost umožňuje, či naopak neumožňuje. Participační chování je tak výslednicí vnitřních intencí i vlastností žáka a podmínek, v nichž se žák nachází.

\section{Cíle této studie a výzkumné otázky}

V souladu s tezemi uvedenými výše považujeme nerovnosti $\vee$ žákovských participačních vzorcích za kličcvé téma, které je třeba zkoumat. Souhlasíme s Lefsteinem a Snellovou (2014), že dobrá výuka je taková, která podněcuje žáky k participaci. Vidíme přitom jako významné, aby byl dialog ve třídě kolektivní, to znamená, aby se zapojovali pokud možno všichni žáci (Alexander, 2006). Domníváme se, že porozumět problému participačních vzorců není možné bez detailního prozkoumání žákovské perspektivy. Jinými slovy, zajímá nás, jak sami žáci pohližejí na svůj způsob zapojení do výukové komunikace. Poučeni předchozími výzkumy přitom víme, že žákovské charakteristiky a jejich identita hrají klíčovou roli. Proto jsme se rozhodli založit tuto studii na hloubkových rozhovorech se žáky, v nichž se žáci vyjadřují k tomu, jak sami sebe vidí jako participanty ve výukové komunikaci a jak sami sebe vidí obecně jako žáky. Doplňkově využíváme též rozhovory s učitelkami těchto žáků, jednak abychom jejich výpovědi triangulovali, jednak abychom postihli situační institucionální kontext, v němž se jejich participace odehrává.

Výzkumné otázky, které si klademe, jsou následující:

1) Jaký význam připisují žáci participaci ve výukové komunikaci?

2) Jaké jsou motivy žáků pro a proti zapojení do výukové komunikace?

3) Jak se mezi sebou v těchto ohledech liši žáci vokální a tiší?

4) Jak se mezi sebou $v$ těchto ohledech liší žáci akademicky úspěšní a žáci akademicky neúspěšní?

\section{Metodologie}

Tato studie byla realizována v rámci projektu Vztah mezi charakteristikami výukové komunikace a vzdělávacími výsledky žákủ, ${ }^{4}$ který byl rozložen do dvou na sebe navazujících etap. V první etapě (ř́jen až prosinec 2017) jsme realizovali kvantitativní šetření, do nějž bylo zahrnuto 32 školních tř́́d. Šlo o žáky 9. ročníku a jejich učitele českého jazyka a literatury. Ve všech těchto třídách v daném období Česká školní

4 Řešitelský tým pracuje ve složení: Klára Šed’ová, Martin Sedláček, Roman Švaříček, Martin Majcík, Jana Navrátilová, Anna Drexlerová, Zuzana Šalamounová. 
70 inspekce prováděla výběrové šetření čtenářské gramotnosti a výsledky testů jednotlivých žáků jsme dostali k dispozici. Dále jsme v každé ze tříd realizovali strukturované pozorování dvou hodin literatury s cílem změřit kvantitu a kvalitu participace jednotlivých žáků ve výukové komunikaci. Kromě toho jsme sbírali řadu dalších dat o žácích, zajímali jsme se o jejich prospěch, sociometrický status ve třídě či o to, jak jsou hodnoceni svými učiteli. Data z kvantitativní etapy výzkumu nám slouží především ke zkoumání, zda individuální zapojení do komunikace souvisí se školní úspěšností žáků. Naše dosavadní analýzy (Šed’ová et al., 2019) ukázaly, že ano. Lapidárně řečeno platí, že kdo ve výuce více mluví, se také více naučí.

Druhá etapa našeho projektu má kvalitativní charakter. Z původního vzorku jsme získali $k$ další spolupráci čtyřri učitele a jejich třídy. $V$ těchto tř́idách jsme provedli terénní etnografické šetření (únor až květen 2018) zahrnující videonahrávky výuky a hloubkové rozhovory s učiteli i se žáky. Cílem této kvalitativní etapy bylo detailněji rozkrýt participační vzorce ve sledovaných třídách a také zachytit významy, které jsou participaci připisovány ze strany žáků i jejich učitelů. Jinými slovy, chceme vědět, kdo se do komunikace zapojuje, jaké $\mathrm{k}$ tomu má motivy a jaké důsledky $\mathrm{z}$ toho pro něj plynou. A inverzně též, kdo se do komunikace nezapojuje, jaké k tomu má motivy a jaké důsledky z toho pro něj plynou. Tato studie je jedním z výstupů kvalitativní etapy námi realizovaného šetření.

\subsection{Vzorek}

Výzkumu se účastnily čtyři školní třídy, každá $z$ jiné školy. Tři školy $(A, B, C)$ byly venkovské (pouze jedna škola v obci), jedna škola (D) naopak velkoměstská. V každé ze tříd jsme si předem vytipovali čtyři fokální žáky, a to tak, abychom pokryli následující kategorie: (a) prospěchově silný vokální žák, (b) prospěchově silný tichý žák, (c) prospěchově slabý vokální žák, (d) prospěchově slabý tichý žák. Rozhodovali jsme se jednak na základě známek žáků z předmětu český jazyk a literatura, jednak na základě dat ze standardizovaného pozorování žákovské participace realizované $\checkmark$ předchozí fázi výzkumu. Co se týče známek, $v$ př́padě úspěšných žáků nám šlo o to, aby daný žák patřil do skupiny nejlépe hodnocených v daném předmětu. Všichni námi vybraní úspěšní žáci měli na vysvědčení jedničku nebo dvojku ( $v$ takovém př́ipadě šlo o dvojku, kterou samy učitelky považovaly za hraničící s jedničkou). U neúspěšných šlo analogicky o to, aby daný žák patřil do skupiny nejhůře hodnocených $v$ daném předmětu. Všichni námi vybraní neúspěšní žáci měli na vysvědčení trojku (v některých tř́idách šlo o nejhorší udělenou známku z daného předmětu) nebo čtyřku. Co se týče komunikativnosti, řídili jsme se daty ze strukturovaného pozorování. Hodnoty naměřené $v$ jednotlivých třídách byly velmi rưzné. Platí však, že vokální žáci vždy patřili do skupiny nejčastěji a nejdéle hovořících žáků v dané tř́dě. Naopak tiši žáci v měřených hodinách hovořili jen málo nebo vůbec. Výběr fokálních žáků jsme následně vždy validizovali v rozhovoru s jejich učitelkami.

Vzorek, s nímž pracujeme $v$ této studii, tvoří 16 fokálních žáků ze čtyř tríd a jejich učitelky českého jazyka a literatury. Jednotlivé participanty stručně charakte- 
rizujeme $v$ tabulce 1 . Limitem této studie je skutečnost, že jsme fokální žáky vybírali jako extrémní prípady jak z hlediska participace, tak prospěchu. Analýza tedy nemúže nijak osvětlit situaci prospěchově $a / n e b o$ participačně průměrných žáků.

Tabulka 1 Charakteristiky vzorku

\begin{tabular}{|c|c|c|c|c|c|}
\hline Třída & Učitelka & Délka praxe & Kontakt učitelky se třídou & Žák & Charakteristika žáka \\
\hline \multirow[t]{4}{*}{ A } & \multirow[t]{4}{*}{ Aneta } & \multirow[t]{4}{*}{4 roky } & \multirow{4}{*}{$\begin{array}{l}\text { Vyučuje ve třídě A český } \\
\text { jazyk a literaturu již čtvrtým } \\
\text { rokem, po stejnou dobu } \\
\text { ve tř́idě působí jako třídní } \\
\text { učitelka. }\end{array}$} & Anna & vokální jedničkářka \\
\hline & & & & Alena & tichá jedničkářka \\
\hline & & & & Arnošt & $\begin{array}{l}\text { vokální trojkař/ } \\
\text { čtyřkař }\end{array}$ \\
\hline & & & & Andrea & tichá čtyřkařka \\
\hline \multirow[t]{5}{*}{ B } & \multirow[t]{5}{*}{ Beata } & \multirow[t]{5}{*}{13 let } & \multirow{5}{*}{$\begin{array}{l}\text { Třída B vznikla sloučením } \\
\text { dvou různých tříd po } \\
\text { 7. ročníku. V jedné z těchto } \\
\text { pưvodních tříd Beata } \\
\text { vyučovala český jazyk } \\
\text { a literaturu již od 6. ročníku, } \\
\text { ve druhé nikoli. S částí třídy } \\
\text { tedy pracuje čtvrtým rokem, } \\
\text { s částí třídy druhým rokem. }\end{array}$} & Boris & vokální dvojkař \\
\hline & & & & Blanka & tichá jedničkářka \\
\hline & & & & Bohumil & vokální čtyřkař \\
\hline & & & & Barbora & tichá čtyřkařka \\
\hline & & & & & \\
\hline \multirow[t]{4}{*}{ C } & \multirow[t]{4}{*}{ Chantal } & \multirow[t]{4}{*}{2 roky } & \multirow{4}{*}{$\begin{array}{l}\text { Vyučuje ve třídě C český } \\
\text { jazyk a literaturu druhým } \\
\text { rokem. }\end{array}$} & Claudia & vokální jedničkářka \\
\hline & & & & Ctibor & $\begin{array}{l}\text { tichý jedničkář/ } \\
\text { dvojkař }\end{array}$ \\
\hline & & & & Cesar & vokální trojkař \\
\hline & & & & Cyril & tichý trojkař/čtyřkař \\
\hline \multirow[t]{4}{*}{ D } & \multirow[t]{4}{*}{ Daniela } & \multirow[t]{4}{*}{15 let } & \multirow{4}{*}{$\begin{array}{l}\text { Vyučuje ve třídě } D \text { český } \\
\text { jazyk a literaturu teprve } \\
\text { prvním rokem, avšak již } \\
\text { čtvrtým rokem vyučuje } \\
\text { v této třídě dějepis. }\end{array}$} & Dita & vokální jedničkářka \\
\hline & & & & David & $\begin{array}{l}\text { tichý jedničkář/ } \\
\text { dvojkař }\end{array}$ \\
\hline & & & & Dalibor & vokální trojkař \\
\hline & & & & Denis & tichý trojkař/čtyřkař \\
\hline
\end{tabular}

\subsection{Data}

Ve všech třídách jsme natočili šest videonahrávek výuky v předmětu český jazyk a literatura s cílem zachytit dění ve výuce a způsoby, jimiž se jednotliví žáci zapojují do komunikace. Vyučovací hodiny, které jsme snímali, byly věnovány různým obsahům. ${ }^{5}$ Sjednocení nebylo možné vzhledem $\mathrm{k}$ tomu, že v každé škole byl tematický

5 Jednotlivé sledované lekce byly věnovány těmto tématům: Tř́da A: 1) Předpony $s / z$, druhy vět vedlejších; 2) Karel Kryl - život a dílo, analýza písňového textu; 3) Jaromír Nohavica - písňové texty; 4) Reportáž jako slohový útvar; 5) George Orwell - život a dílo; 6) Slovní druhy, druhy vět vedlejších. Třída B: 1) Referát jako slohový útvar; 2) Jan Skácel - analýza básně; 3) Výklad jako slohový útvar; 4) Př́stavky; 5) Výklad, analýza textu; 6) Větná interpunkce a větné členy. Třída C: 
72 plán jiný a naším cílem bylo sledovat výuku v přirozených podmínkách s minimální intervencí z naší strany. Ve všech čtyřech tř́dách převažovala frontální výuka, kdy žáci seděli ve dvojicích v lavicích a učitelky řídily konverzaci prostřednictvím IRF struktury (Šed'ová, Švaříček, \& Šalamounová, 2012).

Kromě záznamů výuky jsme provedli hloubkový polostrukturovaný rozhovor s každým ze šestnácti fokálních žáků. Rozhovory trvaly přibližně 30 minut. Vždy byly realizovány ve dvojici žák a výzkumník, ${ }^{6}$ a to během vyučování (žáci byli po danou dobu uvolněni z lekce), v prostorách školy, $v$ místnosti, kde nebyl př́tomen nikdo jiný (volný kabinet či učebna). Měli jsme připravené měkké dotazovací schéma, které zahrnovalo následující okruhy: sebekoncepce žáků, vnímání vlastní participace a motivace k ní, vnímání participace spolužáků a motivace k ní, vnímání vrstevnických vztahů ve tř́dě, prítomnost obav z chybného výkonu.

Dále jsme pořídili dva rozhovory s každou učitelkou. Délka rozhovorů byla $v$ rozpětí 40-70 minut. Rozhovory se odehrávaly ve dvojici učitelka a výzkumník na klidném místě (většinou ve škole, $v$ některých případech v domácnosti učitelky). První rozhovor byl natočen před začátkem videonahrávání. Měkké dotazovací schéma zahrnovalo následující okruhy: vnímání žáků v dané třídě, jejich potenciálu, komunikativnosti a snahy; pojetí vlastní výuky; význam připisovaný žákovským promluvám; strategie vyvolávání žáků; vnímání vrstevnických vztahů ve třídě. Druhý rozhovor byl realizován vždy po pořízení všech videonahrávek a také po pořízení všech rozhovorů se žáky $v$ dané tř́idě. Otázky byly připravovány pro jednotlivé učitele individualizovaně a týkaly se konkrétních komunikačních jevů př́tomných $v$ jednotlivých třídách.

$V$ této studii pracujeme vzhledem ke zvoleným výzkumným otázkám pouze s daty $z$ rozhovorů. Celkem máme $k$ dispozici 16 rozhovorů se žáky a 8 rozhovorů s jejich učitelkami. Celý datový materiál byl doslovně přepsán a tvoří asi 220 stran textu.

\subsection{Analýza}

Analýza dat proběhla za použití softwaru ATLAS.ti. Data od žáků i učitelek byla nejdřive volně induktivně okódována a seskupena do kategorií. Následně jsme postupovali tak, že jsme se u každého ze žáků soustředili na tři kategorie: 1) sebekoncepce popisy sebe sama jako žáka, 2) participační profil - reflexe vlastního participačního chování, 3) důvody pro a proti participaci - benefity a rizika uváděné v souvislosti s participací. Nejprve jsme pracovali s daty od každého žáka zvlášt', následně jsme žáky sloučili do skupin v souladu s nastavením vzorkování. Dále jsme tedy např́klad skupinu vokálních úspěšných zpracovávali jako celek. Soustředili jsme se na hledání

1) Opakování gramatických jevů na přijímací zkoušky; 2) Božena Němcová - život a dílo; 3) Jan Neruda - život a dílo; 4) Jan Neruda - život a dílo; 5) Vítězslav Hálek a Karolína Světlá - život a dílo; 6) Karolína Světlá a Jakub Arbes - život a dílo. Třída D: 1) Čtení a interpretace textu z knihy Josteina Gaardera Sofiin svět; 2) Čtení a interpretace textu z knihy Josteina Gaardera Sofiin svět; 3) Čtení a interpretace textu z knihy Deník Anny Frankové; 4) Ćtení a interpretace textu z knihy Charlotte Brontëové Jana Eyrová; 5) Větné členy; 6) Proslov jako slohový útvar.

6 Dotazování vedli: Jana Navrátilová (třída A), Martin Majcík (trrída B), Roman Švaříček (tř́ida C) a Klára Šed’ová (tř́da D). 
sdílených rysů uvnitř každé skupiny a následně naopak na identifikaci rozdílů mezi odlišnými skupinami. Tímto způsobem jsme komparativní analýzou došli k vystižení specifických žákovských i participačních charakteristik vlastních jednotlivým skupinám.

$\mathrm{U}$ učitelek jsme postupovali analogicky. Z rozhovorů jsme vybrali pasáže, v nichž učitelky referovaly o některém ze žáků $v$ našem vzorku, a tyto pasáže jsme rozčlenili podle jednotlivých skupin. Měli jsme tak k dispozici např́ílad soubor výpovědí o vokálních úspěšných. Soustředili jsme se na: 1) učitelskou koncepci žáků - popisy chování a charakteristik žáků, 2) učitelskou reflexi jejich participačního profilu vyprávění o tom, jak žáci participují. Opět jsme hledali shody uvnitř jednotlivých skupin a rozdíly napříc nimi. Záhy se vynořily poměrně silné vzorce, na nichž se k našemu určitému překvapení - shodovali žáci i učitelky.

\subsection{Etika výzkumu}

Na počátku výzkumu jsme uzavřeli dohodu o spolupráci s Českou školní inspekcí a následně kontaktovali školy zahrnuté do testování. Poté, co jsme získali souhlas ředitelů škol a př́slušných učitelů (to se podařilo v 21 z 23 oslovených škol), jsme prostřednictvím učitelů získali od všech rodičů písemný souhlas s účastí dětí ve výzkumu. Veškerá data byla pečlivě anonymizována. $V$ kvalitativní etapě výzkumu jsme ve vybraných čtyřech tř́́dách znovu učinili dohodu se všemi zainteresovanými aktéry a distribuovali jsme nový formulář pro rodiče obsahující písemný souhlas s videonahrávkami výuky a s pořizováním rozhovorủ se žáky. Všichni účastníci byli ujištěni o důvěrnosti dat a o možnosti kdykoli z výzkumu odstoupit. Tuto možnost nikdo z účastníků v průběhu šetření nevyužil. Při zpracování dat jsme všem participantům přidělili pseudonymy, pod nimiž vystupují také v této studii.

\section{Výsledky}

\subsection{Kdo umí, ten se hlásí}

V rozhovorech se žáky zaznívala v mnoha variantách otázka, za jakých okolností se přihlásí o slovo. Nejběžnější a nejspontánněji vyslovovaná odpověd' zněla, že tehdy, kdy znají odpověd' na položenou otázku. Tuto tezi vztahovali žáci jak sami k sobě („,hlásím se, když vím“), tak ke svým spolužákům („hlásí se, protože vědí“). Jedničkářka Claudia říká: „Když to vím, tak se přihlásím, a zase když to nevím, tak se nechcu hlásit, aby to nebylo takové blbé. “Velmi podobně na otázku, kdy se zapojuje do komunikace, reaguje žákyně z opačné strany výkonnostního spektra, čtyřkařka Barbora: „Když něco vím, tak odpovím, když nevím, tak neodpovím.“ Vidíme, že tendence zapojovat se $v$ př́padě bezpečné znalosti je univerzální, funguje u žáků s výborným prospěchem, stejně jako u žáků slabých. Za zdráháním odpovídat v príipadě, že si žák není svou znalostí jist, stojí obava z chyby. To je zřetelné z rozhovoru tazatele s Alenou: 
Tazatelka: Kdy se hlásíš víc a kdy míň?

Alena: No záleží na tom učivu, a jak tomu rozumím.

Tazatelka: A bojišs se, že odpovišs špatně někdy?

Alena: Ale to se spiš většinou nepřihlásím.

Tendenci mluvit pouze $v$ případě bezpečné znalosti je možné považovat za jakési defaultní nastavení ve třídě. Jak ukážeme v další analýze, existují skupiny žáků, které jsou s to ji překročit. Na tomto místě ještě dodáme, že žáci dokážou citlivě odlišovat, zda je komunikace $v$ dané chvíli zaměřena na prezentování vědomostí, nebo vyjadřování názorů. Jsou-li vyzýváni k vyjádření názoru, bariéry zapojení poněkud odpadají. Blanka, která patří mezi spíše tiché žáky, k tomu říká:

Tazatel: A když si představím, když už teda určitě někdy v hodinách jakoby mluvišš, když ti to není príjemné, tak co to jsou za situace?

Blanka: Když třeba něco bereme, tak se občas jako přihlásím. Ale to je většinou, když mưžeme říct svưj názor a já bych $\mathrm{k}$ tomu zrovna něco chtěla říct, tak to se přihlásím a řeknu to.

Tazatel: Tam už se ale nebojíš, že bys třeba udělala chybu?

Blanka: Ne, protože tam říkám jakoby svůj názor.

Blanka patři mezi žáky, které velmi inhibují obavy z chybného výkonu či neúspěchu (viz dále). Z citace však vyplývá, že ve chvíli, kdy cílem participace není odpovědět na vědomostní otázku, ale říci svůj názor, její obavy ustupují. Totéž lze vidět u Dalibora, který je spiše slabý žák, avšak do konverzace ve třídě se zapojuje hojně. Dělá to především ve chvílích, kdy se neprověřují znalosti:

Dalibor: U nás $v$ češtině se řeší zrovna takový věci, do kterých se rád zapojím. At' už jsme tam třeba řešili ty knížky, nebo už pak obecně takový blbosti, tak jako do každé debaty jsem schopen se nějakým způsobem zapojit.

Tazatelka: A máš to tak ve všech předmětech?

Dalibor: No, ne úplně ve všech předmětech se dá takhle diskutovat. Třeba v občance je to podobný a řeši se tam nějaký ty věci názoru, někdy i třeba v přírodopise, ale jinak matika, fyzika a chemie, to už je trošku něco jinýho. Takže co se týče zapojování, tak když je něco, u čeho stačí jen to mluvení, tak mi to vůbec nevadí se zapojit.

Dalibor citlivě identifikuje momenty, kdy „stačí jen to mluvení“, což jsou situace, kdy je ve třídě navozena diskuse nebo kdy učitel zkrátka položí otevřenou otázku nevyžadující faktické znalosti. Domnívá se, že je schopný diskutér („do každé debaty jsem schopen se nějakým způsobem zapojit“). Zde je jistá paralela s tím, za jakých okolností se žáci vyjadřují k vědomostním otázkám - dělají to tehdy, kdy se neobávají selhání. Do vyjadřování názorů se žáci pouští rovněž, nebojí-li se, že selžou, jen vstupní kapitál je jiný. Není to faktická znalost, ale konverzační obratnost a schopnost rychlého vyjádření. Lze tedy souhrnně říci, že strach z neúspěchu, a naopak vyhlídka na úspěch tvoří hlavní a univerzální - bez ohledu na prospěch či míru komunikativnosti žáků - hybné síly, které rozhodují o tom, zda se žáci zapojí, či nikoli. 
Platí přitom, že se žáci mezi sebou sledují a vyhodnocují účast ostatních v komunikaci jako indikátor nejen jejich znalostí, ale obecně inteligence. Slabší a málo komunikativní žák Denis v rozhovoru nejprve správně označil spolužáky, kteří ve vyučování hodně mluví, a následně se $k$ jejich motivaci vyjádřil takto: „Tak asi, že jsou takoví a asi i vědí dost. "Vidíme, že samotné zapojení je bráno jako indikátor kompetentnosti. Drtivá většina našich respondentů byla schopna identifikovat vokální spolužáky a hovořila o nich pozitivně. Když jsme v rozhovorech žádali, aby uvedli, kdo ze spolužáků naopak mluví málo a proč, byl odhad respondentů opět většinou správný, přičemž jako důvod pro nemluvnost byla typicky uváděna neschopnost těchto žáků. Takto např́klad Dita hovoří o své spolužačce Darině:

Tazatelka: 0 kom bys řekla, že ve třídě nemluví?

Dita: Darča.

Tazatelka: A proč myslíš, že Darča?

Dita: Ona jako nemá moc přehled o světě. Jako vůbec. Že by třeba neřekla, že Vltava protýká Prahou, nebo takhle. Nemá prostě takový inteligenční schopnosti.

Výše jsme uvedli, že hlavní bariérou zapojení je pro žáky strach ze selhání. Zajímavé ovšem je, že se v rozhovorech se žáky jen velmi zř́dka objevují historky o tom, jak se někdo ze spolužáků znemožnil svou promluvou. Zdá se tudíž, že obava ze zapojení má poněkud chimérický charakter. Jako neinteligentní a neschopní nejsou vnímáni ti, jejichž výroky jsou nesprávné či zmatečné, nýbrž ti, kteří nehovoří vůbec.

\subsection{Sebepojetí žáků a důvody pro a proti participaci}

Výše jsme popsali některé univerzální tendence ve vnímání žákovské participace. Dále se budeme věnovat rozdílům mezi různými skupinami žáků. Náš vzorek jsme konstruovali tak, aby v něm byli zastoupeni jak žáci s výborným, tak žáci se slabším prospěchem. Dále jsme do vzorku zahrnuli rovnoměrně žáky vokální a žáky tiché. Zkřížením těchto dvou kritérii vznikly čtyři skupiny žáků: 1) vokální úspěšní, 2) tiší úspěšní, 3) vokální neúspěšní, 4) tiší neúspěšní. Při analýze dat se ukázalo, že žáci patřící do té které skupiny vykazují vždy poměrně homogenní sebepojetí a také uvádějí obdobné důvody, proč se zapojit do výukové komunikace. Naopak mezi sebou navzájem se jednotlivé skupiny zřetelně odlišují.

\subsubsection{Vokální úspěšní}

Do této skupiny spadají z našeho vzorku Anna, Boris, Claudia a Dita. Vidí se jako dobří, ale nikoli dokonalí žáci, zdůrazňují, že mají co zlepšovat. U všech (s výjimkou Borise) je patrná silná ambicióznost doprovázená ochotou tvrdě pracovat na svém úspěchu. Claudia říká: „Snažím se být co nejlepší, protože chci něco dokázat." Podobně Anna v rozhovoru uvedla: „Já mám prostě nějaký svoje daný a vytčený cíle,“ a popsala se následovně: 
Tazatelka: Když by ses měla charakterizovat, jaký jsi žák, co bys řekla? Anna: Aha... (smích) Asi snaživej.

Tazatelka: Snaživej? Co to znamená?

Anna: Že mně to není jako úplně jedno. Že když mi to prostě nejde a už jako fakt mi to nejde, tak se jako naštvu a jsem schopná nad tím učením strávit celej den.

Tito žáci sami sebe vnímají jako inteligentní - např. Dita s odzbrojující bezprostředností prohlašuje: „Mám inteligentní názory.“ Kromě toho je jim společná hovornost jako osobní rys: „Jsem hodně jako aktivní nebo ukecaná...“ (Anna) - „Hodně se hlásím, protože mám takovou povahu...“ (Boris) Pro tyto žáky je výuková komunikace druhem zábavy. Dita na otázku, proč ve vyučování nemlčí, odpovídá: „Protože by mě to nebavilo. Já jsem takovej komunikativní člověk a nedokázala bych jenom sedět, poslouchat a něco si psát.“

Uvedené vlastnosti předjímají způsob zapojení těchto žáků do komunikace. Uvedli jsme, že bariérou participace je především strach ze selhání. Tito žáci však jen zřídka očekávají, že nebudou mít potřebné znalosti, nebot' se do hodin připravují. Stejně tak se neobávají prezentovat své názory, nebot' se považují za inteligentní a přemýšlivé. A konečně, do hovoru s učitelem se nemusí nutit, berou jej jako způsob, jak se $v$ hodině zabavit.

Na otázku, k čemu je dobré se v hodinách zapojovat, mají vokální úspěšní žáci celou řadu odpovědí. Mezi nimi dominují dva okruhy. Za prvé tito žáci věří, že zapojení do komunikace podporuje učení. Jak říká Boris: „Já si to pak spíš zapamatuji, i třeba u tabule, tam si toho víc zapamatuji, než když jsem jenom v té lavici a koukám na tu tabuli, ale když přijdete $k$ té tabuli, tak tam je to úplně o něčem jiném, tam si to vyzkoušíte na vlastní kưži. “ Vedle prostého zapamatování respondenti zdůrazňují vztah mezi řečí a vyššími kognitivními operacemi. Slovy Dity, pokud žák dává pozor a hovoří, „se mu ten okruh myšlenek vlastně otevírá a začne přemýšlet nad různýma věcma“. Velmi sofistikovaně popisuje mechanismus vztahu mezi řečí, učením a myšlení Anna:

Já se snažím hlásit co nejvíc, protože čím víc se hlásím, tak tím víc to ten mozek donutí, jak si to zapamatovat... Když jsou nějaký ty těžší otázky, tak prostě jsem donucena se nad tím jako zamyslet. Když je to ale nějaká lehčí otázka typu jaký „¡“ tam bude, tak to prostě vědí všichni, že jo. Ale když budu přemýšlet nad něčím tím těžším, tak prostě ten mozek to donutí si to jako nějak přebrat a prostě si to jako líp zapamatuju třeba.

V této citaci je pozitivně hodnocena kognitivní výzva, kterou představují obtížné otázky. Vokální úspěšní žáci vnímají pozitivně situace, které jsou pro ně náročné. Jsou totiž natolik sebevědomí, že si riziko selhání př́liš nepřipouštějí (i když i u nich jsou obavy místy př́tomné, což se týká zejména Claudie). Jejich vysoká sebedůvěra zde působí jako protektivní faktor.

Druhým zmiňovaným důvodem pro zapojení do komunikace je snaha vyjít vstříc učiteli, který klade otázky a očekává odpovědi. Zčásti má tato snaha velmi pragmatický charakter - jde o vylepšení hodnocení. Mohlo by se zdát, že úspěšní žáci si nepotřebují pomáhat tímto způsobem, opak je však pravdou, ačkoli se v tomto 
případě hraje o drobné nuance mezi jedničkou a dvojkou na vysvědčení. Jak říká Claudie: „Když potom je třeba pololetí a mám to nějak nerozhodně. Tak možná ti učitelé se na to dívají, jakože jak spolupracuju v té hodině. Tak možná to má asi pro mě výhodu. Značnou. “ V uvedené citaci je symptomatickým termínem spolupráce, přičemž spolupracovat znamená vyhovět učiteli. Anna k tomu dodává: „Že když vidí, že jako fakt se snažíme, tak si řeknou jo, ta o tu lepší známku stojí.“ Komunikativnost a obecně snaha plnit požadavky učitele jsou tak určitými platidly ve směně, z niž vokální úspěšní žáci vycházejí obvykle s nejlepším možným hodnocením.

Vedle tohoto „obchodního“ př́stupu má však snaha vyhovět učiteli též své altruistické aspekty. Claudia popsala svoji motivaci k participaci takto:

Claudia: Vždycky, vždycky, když to vím, tak se většinou přihlásím, protože je to potom takové, že nikdo nic neříká, paní učitelka čeká a neví, co jako dál.

Tazatel: Že jako čeká, kdo odpoví jo?

Claudia: Kdo se přihlásí, no.

V citaci pozorujeme empatii k učitelce, která je neochotou žáků odpovídat uváděna do nekomfortní situace a problematizuje se její výukový postup („neví, co jako dál“). Podobně se vyjadřuje Dita, když popisuje, proč je důležité dávat pozor a reagovat na učitele:

A hlavně učitel vidí ten impulz, že to učení aspoň pro těch pár žáků něco znamená. Třeba ve fyzice jsem dávala pozor jenom já a Dan a ta učitelka to třeba ř́ká jenom nám dvoum... Když má ten učitel zpětnou vazbu, tak je rád a my jsme taky rádi, že po nás nekřičí nebo není naštvanej a tak.

Opět je zřejmý altruistický důraz na to, aby se učitelé necítili neoceněni. Zároveň se altruismus vztahuje k třídnímu kolektivu, ostatní žáci jsou aktivitou spolupracujících žáků chráněni před hněvem učitele. Jde o situaci, z niž svým zpưsobem těží všichni - učitel má dobrý pocit z toho, že žáci spolupracují, vokální úspěšní žáci se učí, zbylí žáci mají klid.

\subsubsection{Tiší úspěšní}

Mezi tiché úspěšné žáky patří Alena, Blanka, Ctibor a David. Sami sebe charakterizují jako dobré a angažované žáky. Jak říká Alena: „Já si myslím, že se učím dobře. A poslední dobou mě učení dost baví, si myslím. " Na rozdíl od vokálních úspěšných je však těmto žákům velmi nepř́jemné, mají-li hovořit před třídou. Vysvětlují to svými povahovými vlastnostmi. Charakterizují se jako úzkostní introverti. To dokládá následující citace Blanky:

Blanka: Já jsem jakoby ze všeho nervní, takže... Já mám totiž hroznej strach, že tam něco pokazím a že se mně všichni budou smát. Takže takhle spíš.

Tazatel: Aha. A stává se to? Nebo spíš, stalo se ti to už? Že jsi třeba něco pokazila, nebo spíš máš jen takovej pocit?

Blanka: Spíš mám takovej pocit.

Tazatel: Ale nestalo se ti to ještě? 
Blanka: Ne.

Tazatel: Dá se s tím nějak bojovat? S tím pocitem?

Blanka: Moc ne... (smích)

Zde se ukazuje vysoká emoční intenzita („,hroznej strach“) spojená s participací. Silné negativní emoce jsou mnohdy založeny spíše na představách žáků než na reálných zážitcích („spišs mám takovej pocit“), přesto jsou pro tyto žáky obtížně zvladatelné („dá se s tím nějak bojovat - moc ne“). Tiší úspěšní žáci ve skutečnosti jen zrrídka něco pokazí či řeknou špatně, nebot' míru své participace značně omezují. Lze říci, že tito žáci pozorně sledují úroveň výkonů svých spolužáků a zapojují se $v$ okamžiku, kdy jsou si jistí, že jejich znalosti či myšlenky budou oceněny jako nadstandardní. Platí to pro situace, kdy učitel testuje znalosti žáků. Ctibor podotýká: „Většinou se hlásím, když jsem si stoprocentně jistý. “ Stejně tak to platí pro situace, kdy mají žáci volně prezentovat své názory či zkušenosti, jak ilustruje rozhovor s Davidem:

David: Je mně docela nepříjemný, když mě nějakej učitel vyvolá a mám stát před třídou, ale třeba když jsme si vybírali téma na ročníkovku, tak jsem si vybral akvaristiku, protože jsem akvarista už od šesti let. Tak to mně jako nevadilo a spíš mě to bavilo. Tazatelka: To, že jsi to prezentoval před třídou?

David: Jo. Prostě, to, co mi jde, tak mi nevadí prezentovat.

Ročníková práce je ve třídě $D$ poměrně komunikačně náročný formát - žáci musí nejenom shromáždit informace a napsat souvislý text, ale též přednést několikaminutovou prezentaci před tř́́dou. David si zvolil oblast, v níž se bezpochyby orientuje mnohem lépe než spolužáci, nebot' nikdo jiný ve třídě se akvaristikou nezabývá. $\mathrm{K}$ úkolu přistoupil tak, že své spolužáky zahrnul mnoha detailními odbornými informacemi a dokázal si svoji prezentaci užít.

To, že David pronesl před třídou dlouhou souvislou řeč, bylo podmíněno tím, že šlo o úkol, který dostal od učitelky zadaný a nemohl se mu vyhnout. Tím se dostáváme $k$ dalšímu rysu, jenž je tichým úspěšným společný, že totiž hovoří až na výzvu učitele. Zároveň mezi nimi a učitelem existuje určité spojenectví. Tiší úspěšní se domnívají, že jejich učitelé vědí, že tito žáci jsou schopní a umí, i když působí pasivně a sami se nehlásí. Pěkně popsáno je to v rozhovoru s Blankou: „Paní učitelka jakoby ví, že třeba já to vím, ale já se nebudu hlásit, protože mám právě strach, že to bude špatně, i když je to třeba dobře... Když se zeptá, jestli někdo ví správnou odpověd', a nikdo se nepřihlásí, tak mě vyvolá, protože si myslí, že to vím. “ Naše data ukazují, že ačkoli je pro tiché úspěšné žáky velmi náročné v hodině hlasitě promlouvat, faktu, že si jich učitelé všímají a dokázali rozpoznat jejich schopnosti, si považují.

Když jsme se tichých úspěšných žáků v rozhovorech ptali, proč je dobré ve výuce mluvit, dostali jsme některé odpovědi podobné jako od vokálních úspěšných, např. podle těchto žáků participace posiluje učení: „Že si v tý hodině víc zapamatuju a nemusím se to pak učit doma." (Alena) Stejně tak tito žáci souhlasí, že si lze 
pomocí verbální aktivity $v$ hodině vylepšit známku. 0 obou těchto benefitech však tito respondenti hovoří vlažně a na rozdíl od vokálních úspěšných je nevnímají jako silné, imperativní důvody pro zapojení. Jak říká David: „Někdy je prostě šance díky mluvení v hodině získat body nebo známku úplně zadarmo. Ale nevím, no. Já spíš prostě mlčím.“

Vidíme tedy, že ačkoli tiší úspěšní žáci rozpoznávají určité přínosy participace, bariéry v podobě studu a nepř́jemných pocitů jsou př́liš silné. Tito žáci opakovaně udávají, že ponechávají prostor ostatním. Jak říká Ctibor: „Já to radši nechávám na ostatních, at' se přihlásí oni. “ Za tímto prohlášením není jen alibistická snaha vyhnout se nepř́ijemnému, ale autentický zájem o to, aby žáci, kteří chtějí hovořit, k tomu dostali př́ležitost - slovy Aleny: „Mě zajímá, co si myslí někdo jinej.“ $\checkmark$ předchozím oddíle jsme uvedli, že motivace vokálních úspěšných $k$ participaci je $v$ jistém smyslu altruistická, nebot' chrání třídu před trapným tichem. Lze říci, že podobně altruistická je i motivace tichých úspěšných, kteří nechtějí zbytečně okupovat komunikační prostor. Tato velkorysost se mísí s pochybami o sobě, čímž se zábrany vstoupit do komunikace posilují. Úryvek z rozhovoru s Davidem to trefně dokresluje:

David: Když třeba děcka mají rozpoutanou debatu v nějaké skupince, tak jim do toho nechci vstupovat.

Tazatelka: Takže i když máš třeba jiný názor, tak jim to neřekneš.

David: Ne, já jim to nechci moc kazit.

Tazatel: Proč kazit?

David: Tak kdyby to nějak mohlo zvrátit tu debatu, nebo by to pak už nebyla taková sranda, tak by to nebylo dobrý.

Ve výsledku dochází k tomu, že tiší úspěšní žáci se drží stranou a do komunikace vstupují teprve tehdy, jsou-li si jistí, že jejich případný příspěvek je exkluzivní, nebot' nikdo jiný ve tř́dě nemá př́slušnou znalost či myšlenku. Zároveň i v takovém př́padě čekají na signál od učitele v podobě zadaného úkolu, vyvolání či neverbálního náznaku, že je jejich zapojení vítané.

\subsubsection{Vokální neúspěšní}

Tuto skupinu v našem vzorku reprezentují Arnošt, Bohumil, Cesar a Dalibor. Společné mají to, že se považují za průměrné žáky, avšak domnívají se, že jejich potenciál je vyšší. Jak ř́ká Dalibor: „Co mi ř́ká většina učitelů i obecně rodiče doma a spolužáci, tak jako nemám úplně nejlepší známky z češtiny ani z ničeho jinýho, ale všichni mi říkají, že nejsem úplně hloupej, ale že na to prostě jen kašlu. "Sdělení, že špatné výsledky nejsou dány nízkou inteligencí či schopnostmi, nýbrž nedostatkem úsilí, zní od těchto žáků unisono. „Kdybych se učil, tak si myslím, že mám na víc, “ ř́ká Cesar. Ještě sebevědoměji hodnotí situaci čtyřkař Arnošt: „Když bych chtěl, tak bych mohl mít jedničky.“

Svoji snahu tito žáci označují jako velmi kolísavou. Slovy Dalibora: „Někdy se na nějakou písemku naučím, někdy prostě ne.“ Zdůrazňují přitom, že jde o věc 
80 volby, mohou se naučit či plnit požadavky učitele, avšak často se rozhodnou to neudělat. Cesar to glosuje: „Když chcu, tak jsem hodný a pracuju, když prostě ne, tak nejsu. Když chcu, tak se snažím, a když nechcu, tak se nesnažím. “ Nabízí se otázka, na základě čeho se tito žáci rozhodují, zda budou, či nebudou do učení investovat svoji energii. Odpověd' všech čtyř je opět shodná: pracují jen tehdy, když je to baví. Arnošt na otázku tazatelky, proč má na vysvědčení čtyřky, když by podle svých slov mohl mít jedničky, vysvětluje: „No, protože mě to nebaví. A mě když něco nebaví, tak já když se mám učit, tak já se učit nebudu, protože mě to nebaví. Když mě to baví, tak já mám tu dvojku klidně. “ Detailnější rozbor, co se skrývá pod formulací „baví mě to“, ukazuje, že zábavné je pro tyto žáky to, co je snadné. Bohumil ř́ká:

Bohumil: Když mně to nejde, tak se, tak mě to prostě štve a prostě mě nenapadne se na to podívat, a když se na to podívám, tak už je docela pozdě na to.

Tazatel: Takže co myslíš, že by mohlo vést k zlepšení třeba tvého prospěchu? Bohumil: No třeba se na to dřív podívat, než když na to píšeme test.

Vidíme diametrální rozdíl oproti výpovědím vokálních úspěšných žáků, kteři pokud jim něco nejde, vyvinou zvýšené úsilí na to, aby danou látku zvládli. Vokální neúspěšné frustrace $z$ obtížného naopak vede $k$ tomu, že učivo ignorují a dávají ostentativně najevo nezájem (,já se učit nebudu, protože mě to nebavi“). Jestliže vokální úspěšní žáci v rozhovorech zdůrazňují svoji pracovitost, vokální neúspěšní jsou na sebe naopak hrdí, když se jim školní požadavky daří zvládat bez námahy. To ilustruje následující úryvek z rozhovoru s Arnoštem:

Arnošt: Tak třeba ten zeměpis, dějepis, to se vůbec neučím. A když píšem, aji z chemie, matiky, tak za mnou sedí holky, tak těm holkám ř́kám: „Holky, tak mi to vysvětlete.“ Holky mi to vysvětlí, já to v tý hlavě udržím a pišu tu písemku a pak to pustím.

Tazatelka: Fakt, jo?

Arnošt: Jó, to já nepotřebuju takový věci držet.

V Arnoštově výpovědi lze rozpoznat jistou blahosklonnost, splní požadavky učitele, přestože jim nepřičítá žádný význam ani užitečnost („to já nepotřebuju“), využívá přitom servisní podpory spolužaček. Svưj způsob zvládání prezentuje beze studu, sám sebe líčí jako toho, kdo má věci pod kontrolou, ovládá ostatní (spolužačky udělají, o co je požádá), rozumně uspoří svoji energii tam, kde není nezbytná.

$Z$ komunikačního hlediska se vokální neúspěšní žáci charakterizují jako velmi aktivní až upovídaní. Arnošt se popisuje takto: „Já jsem takovej člověk, kterej jako furt musí povídat. Já jako nedokážu sedět a mlčet.“ Podobně Cesar: „Jsem prostě takový. Že tam nedokážu prostě sedět $v$ té lavici a nic nedělat, jenom poslouchat. Prostě moc hyperaktivní jsem. “ Vokální neúspěšní žáci tvrdí, že nesnesou nečinnost a mají neustálé puzení $k$ aktivitě. To je někdy nasměruje $k$ vyrušování, zároveň to však vede $k$ tomu, že tito žáci intenzivně komunikují s učitelem o vyučované látce. Bohumil na otázku, kdo se ve třídě nejvíce hlásí, odpovídá: „No tak asi já mluvím nejvíc, protože já tam mám nejvíc takovou prořizlou hubu, jak se říká.“ 
Tím se dostáváme k zajímavému jevu. Uvedli jsme, že obecný vzorec velí žákům zapojovat se ve chvíli, kdy lze očekávat, že jejich př́spěvek bude hodnocen jako správný či kvalitní. Vokální neúspěšní žáci často nedisponují potřebnými vědomostmi, nepřipravovali se, nejsou naučení, přesto jim jejich naturel velí zapojit se do komunikace. Analýza jejich výpovědí ukazuje, že mají odlišnou motivaci pro zapojení do diskuse, v níž jde o to, vyjádřit svůj názor, a pro zapojení v okamžiku, kdy učitel klade vědomostní otázky. Co se týče motivace pro zapojení do debaty, ta je dána tím, že jsou dostatečně sebevědomí, co se týče vlastních komunikačních schopností, pohotovosti a argumentace. Dalibor situaci glosuje následovně:

Dalibor: Ono obecně, když se mě na něco učitelka ptá, tak na to rád zareaguju, protože co se týče argumentování, tak si myslím, že jsem na tom docela dobře. Takže se rád takhle s někým dostanu do debaty, která by měla vyvrcholit $v$ to, že jsme došli $k$ nějakýmu inteligentnímu názoru. A proto mě to i baví v těch češtinách, takže se rád do toho zapojím.

Tazatelka: Takže máš prostě rád ty povídací hodiny.

Dalibor: No, víceméně jo, protože tam člověk nemusí nic dělat a jenom stačí mluvit.

Tazatelka: Mysliš, že to znamená, že nic neděláš, když mluvišs?

Dalibor: No, mně nevadí se u toho zamyslet, protože obecně říct někomu ten svůj názor a ten jeho tím třeba změnit, tak to jsem vždycky rád, když se mi to povede. Nebo abych prostě dokázal, že nějak inteligentní jsem, tak to jako rád udělám.

V citované výpovědi opět nalézáme spojení mezi tím, co je pro žáka snadné („,̌̌lověk nemusí nic dělat“) a co ho baví („,rád se do toho zapojím“). Stejně tak jsou zřetelné vysoké sebevědomí žáka (,,jsem na tom docela dobře“) a očekávání úspěchu $\checkmark$ dané situaci. $v$ tomto ohledu jsou vokální neúspěšní př́mým protipólem tichých úspěšných, kteř́ obtížnou situaci definují opačně: není pro ně těžké nastudovat látku a připravit se, ale veřejně promluvit. V Daliborově výpovědi stojí za pozornost také předpoklad, že debata vyvrcholí vyvozením „inteligentního názoru“. Zdá se, že vyšší kognitivní operace tyto žáky neodrazují, naopak jsou pro ně lákavé. Konverzace ve tř́́dě je pro ně totiž platformou, na níž mohou ostatním ukázat svoji bystrost. To je zcela zřetelné z Daliborovy poslední repliky ve výše citovaném úryvku (,abych prostě dokázal, že nějak inteligentní jsem“). Úspěšní žáci prokazují svoji inteligenci především svými známkami, pro vokální neúspěšné je komunikace ve výuce alternativní možností, jak demonstrovat svůj potenciál.

Vokální neúspěšní žáci vykazují též motivaci odpovídat na dotazy, které vyžadují vědomosti, a to i v prípadě, kdy jimi nedisponují. Tímto se zásadně liší od ostatních skupin ve vzorku. Jako jediní se dokážou povznést nad obavy z chybné odpovědi. Arnošt na otázku, jak se cítí, když v hodině odpoví špatně, reaguje: „No, bóže, no tak stalo se, stalo se. Chybama se člověk učí. “ Touto promluvou velmi dobře vystihuje skutečnost, že vokální neúspěšní žáci silně vnímají pozitivní vztah mezi komunikací a učením. Arnošt dále prohlašuje:

Arnošt: Myslím, že když seš aktivní, tak si toho zapamatuješ víc, než kdybys tady seděl jak pecka.

Tazatelka: Fakt? 
Arnošt: Jo, určitě. Já, když něco povídám, tak si to zapamatuju.

Důraz na př́nos komunikace pro učení je u těchto žáků silnější než u tichých úspěšných, a překvapivě dokonce silnější než u vokálních úspěšných. Domnívají se totiž, že participací v hodině si ušetří práci s domácím učením, které, jak jsme uvedli výše, se snaží minimalizovat. Bohumil ř́ká: „Doma se až tak moc neučím, hlavně během té výuky. “ Dále upřesňuje:

Bohumil: Mně nikdy nešla moc čeština, takže když odpovídám, tak to prostě tuším, že to je tak ze 60 procent špatně.

Tazatel: No, a tak proč se... třeba když jsi říkal, že ostatní se bojí zapojit, takže se radši nezapojí, tak jakoby proč ty se teda zapojuješ, když víš, že to dopadne špatně?

Bohumil: Protože když se zapojím a řeknu to špatně, tak vím, proč je to špatně potom. Tazatel: Jakoby že ti to pomáhá k učení?

Bohumil: No.

Z citace vysvítá, že vokální neúspěšní žáci jsou ochotni vzít na sebe riziko chyby, nebot' si uvědomují didaktický potenciál chybného výkonu. Když ve správný okamžik (tedy nikoli při zkoušení či při testu) odhalí svoji neznalost, mohou ji bez námahy korigovat.

Vedle výše uvedených motivů pro zapojení sdílejí vokální neúspěšní s úspěšnými žáky předpoklad, že díky participaci lze dosáhnout lepší známky. Jak ř́ká Arnošt: „Myslím, že když paní učitelka vidí, že tak jako dobře komunikuju, když mám třeba tu známku nerozhodnou, že si myslím, že mi dá tu lepší.“ Je zde však přece jen určitý rozdíl. Vokální úspěšní žáci se domnívají, že učitel oceňuje participaci jako projev snahy vyhovět mu a plnit jeho požadavky (viz výše). Oproti tomu u vokálních neúspěšných lze vysledovat důraz na to, že prostřednictvím participace prokazují své schopnosti („dobře komunikuju“) a právě tyto schopnosti učitel následně bonifikuje lepší známkou. Slovy Dalibora: „Jo, jako bez mozku by se člověk do debaty nezapojil. Někdy už jen z toho, jak se lidi vyjadřujou, jde poznat, jestli jsou hloupí, nebo ne.“

\subsubsection{Tiší neúspěšní}

Tato skupina sestává z Andrey, Barbory, Cyrila, Denise. Všichni tito žáci se považují za prospěchově průměrné nebo slabé. Na rozdíl od vokálních neúspěšných se domnívají, že na víc nemají, protože jim učení nejde. Cyril, který měl z češtiny na vysvědčení trojku, se $\mathrm{k}$ tomu vyjadřuje takto:

Tazatel: A jakou máš známku v češtině?

Cyril: Trojku.

Tazatel: A jak jsi spokojen s trojkou? Chtěl bys mít lepší?

Cyril: Ne, tohle mi stačí.

Tazatel: Stačí ti to?

Cyril: Jo, zas tak dobrý nejsem.

Vidíme smířenost s výsledky, které Cyril vidí jako v souladu se svým potenciálem („,zas tak dobrý nejsem“). I v př́padě, že vokální neúspěšní žáci se svými známkami 
spokojeni nejsou, zaznívá v jejich promluvách jistý fatalismus - situaci podle nich není možné příliš ovlivnit.

Tazatel: A jaké máš třeba známky ted'ka v češtině?

Barbora: Špatný.... (smích)

Tazatel: A chtěla bys je zlepšit?

Barbora: Jo, ale moc to nejde.

Tazatel: Nejde. A napadá tě třeba zpưsob, jak by to šlo, jestli se tomu věnovat trošku víc, nebo...?

Barbora: Hm, asi se pořád dokolečka učit to samé, abych si to zapamatovala.

V citaci z rozhovoru s Barborou je zjevný radikální rozdíl oproti sebevědomým deklaracím vokálních neúspěšných, kteří prohlašují, že špatné známky jsou věcí jejich volby a bylo by snadné je zlepšit. Barbora vidí ke zlepšení jedinou cestu, a to věnovat větši čas pamětnímu učení („dokolečka se učit to samé“). To je přitom způsob, který vokální neúspěšní aplikují. Jak říká Cyril: „Snažím se, ale mně to zas tak moc nejde.“ Některé školní požadavky jsou zkrátka vnímány jako nezvládnutelné.

Tazatelka: A kdyby sis řekl, že chceš mít za každou cenu jedničku z češtiny, co bys pro to musel udělat?

Denis: No asi se naučit tu mluvnici. Já si tu známku mezi diktátama vytáhnu nahoru, ale tím diktátem si ji zase zkazím.

Tazatelka: A to by nešlo se ten pravopis naučit?

Denis: Ne.

Po komunikační stránce se definují jako plaší a stydliví. Andrea na otázku, jaká je žákyně, odpovídá: „Já si myslím, že tichá... Že se jako hodně stydím před ostatníma, že řeknu třeba něco, co je špatně. “ V tomto ohledu jsou tiší neúspěšní podobní tichým úspěšným. Ti se zapojují jen tehdy, jsou-li si jistí, že jejich příspěvek do komunikace bude nadstandardně kvalitní. Do takové situace se však tiší neúspěšní téměř nedostávají, tudíž si slovo neberou.

Domnívají se totiž, že ostatní spolužáci jsou lepší. Cyril na otázku, proč se podle něj v češtině nejvíc hlásí Claudia, odpovídá: „Ona je taková nejchytřejší. “ Podobně o vokálních spolužácích mluví Andrea: „Hlásí se takoví ti chytřejší.“ Vzhledem k tomu, že se sami o sobě domnívají, že i přes svou snahu školní látku príliš nezvládají, odsuzuje je tento postoj k mlčení. Hovoři o tom, že se jejich spolužáci více prosazují. Andrea na otázku, proč se více nehlásí, reaguje: „Já nevím. Tak ostatní to prostě hned vykřiknou. “ Z analýzy výpovědí však vyplývá, že jim sami záměrně prostor vytváŕí. Denis, když jej v jedné z hodin učitelka vyvolala k tabuli, navrhl, at' jde místo něj jeho školsky úspěšnější spolužák. Nešlo přitom o legraci ani drzosti vưči učitelce, nýbrž o vážně míněný návrh. $V$ rozhovoru se $\mathrm{k}$ tomu vyjádřil následovně:

Tazatelka: Tys tam s paní učitelkou nějak smlouval. Ona ti říkala, at' jdeš k tabuli, a tys ríkal, at' jde soused. Je to tak?

Denis: Jo, to je pravda.

Tazatelka: A proč jsi nechtěl jít?

Denis: Jako já bych tam šel, ale bylo mi blbý, že já půjdu a on ne. 
Tiší neúspěšní žáci, jak se zdá, vyvíjejí aktivní snahu se komunikaci vyhnout. Tím se liší od tichých úspěšných. Ti sami nejsou př́liš iniciativní, ale pokud se na ně učitel obrátí, do komunikace se zapojí a pozornost, kterou na ně učitel upírá, kvitují mnohdy s povděkem. Oproti tomu tiší neúspěšní mají tendenci se úkolu vyhnout a dát přednost spolužákům („,bylo mi blbý, že já půjdu a on ne“). Barbora na otázku, zda je ráda, když ji učitelka vyvolá, odpovídá razantním odmítnutím: „Nevyvolávat!“ Tiší neúspěšní o to, dostat slovo, nestojí, dokonce se tomu snaží zabránit.

Andrea: Když třeba děláme něco v učebnici, tak to se schovám za vlasy a dělám, že tam nejsu.

Tazatelka: A jak to?

Andrea: No já nevím. Když třeba mě vyvolá, tak já mlčím a musí to za mě říct někdo jinej.

Andrea vědomě použivá mechanismus skrývání („se schovám za vlasy“). Jestliže i přesto dojde $\mathrm{k}$ tomu, že je vyvolaná, zưstává v pasivní rezistenci a čeká, až slovo převezme někdo ze spolužáků. Cílem je nepoutat na sebe pozornost okolí, zůstat v určité komunikační izolaci. Vokální neúspěšní žáci se takto chovají i v situaci, kdy podle svých slov dávají pozor, a dokonce i tehdy, kdy je výuka baví. Počínají si tak proto, že pocit’ují př́liš mnoho bariér, které stojí v cestě jejich úspěchu (jsou plaší, nejsou pohotoví, nemají znalosti, necítí se chytří). Naopak lákadel či motivů k zapojení dokážou identifikovat jen velmi málo. Jsou jedinou skupinou ve vzorku, která zpochybňuje možný př́nos komunikace ve vztahu k učení. Barbora svůj názor vyjadřuje takto:

Barbora: Ostatní mluví víc než já.

Tazatel: A čím myslíš, že to je?

Barbora: Já radši poslouchám.

Tazatel: Radši posloucháš. I v tom, co tě baví prostě radši ...

Barbora: Jo, jo.

Tazatel: A máš pocit, že se z toho naučíš stejně, než jako když se třeba zapojíš a řekneš něco, že si to třeba pak lépe nezapamatuješ?

Barbora: Myslím, že to je úplně stejný.

\section{3 Žákovská participace očima učitelek}

Data od žáků doplníme pohledem učitelek. Lze říci, že jejich vnímání žákovské participace je jednoznačně pozitivní. Na otázku, jak se pozná dobrá hodina, unisono odpovídají, že je to hodina, v níž žáci komunikují. Aneta uvádí: „Když reagují jako, když mluví se mnou, když prostě není ticho v tý třídě.“ Podobně Chantal: „Jsou hodiny, kdy mám prostě pocit, jako že jo, to byla dobrá hodina, prostě ani nezlobili a komunikovali, bavili se se mnou.“

Učitelky př́liš netematizují možnost, že se skrze komunikaci žáci učí (na rozdíl od vokálních žáků, kteří to tvrdí velmi dưrazně). Spiše lze říci, že to, jak žáci komu- 
nikují, chápou jako indikátor jejich učení. Daniela na otázku, jak pozná, jestli žáci učivo chápou, odpovídá následovně:

Podle toho, jak se zapojí do té hodiny, jestli to odsýpá, nebo ne, jestli se musím u něčeho zdržet, nebo nemusím. Třeba $v$ té mluvnici, tam bylo vidět, že to chápou, vždycky jsme si to řekli na těch př́kladech, oni chápali, takže jsme mohli jít hned dál. A v těch literárních hodinách asi podle toho, jak se zapojí do té diskuse.

Z citace vyplývá, že podle toho, jak pohotově a správně žáci reagují, učitelka řídí tempo probírání látky a výběr didaktických metod. Komunikace se žáky je pro učitelku nástrojem kontroly jejich porozumění. Podobným způsobem učitelky mohou monitorovat zapamatování faktických údajů. Slovy Chantal:

Tak já většinou začíám hodinu tak, že se jich ptám na to, co jsme dělali minulou hodinu. A když vidím jako, že se orientují, že reagují, tak mám jako takový dobrý pocit, že si z té minulé hodiny něco odnesli. Nemám úplně iluze, že by se průběžně učili, ale když prostě vidím, že prostě, že reagují a že něco z té minulé hodiny si odnesli, tak mě to vždycky potěší.

Ve výpovědi Chantal je patrná důležitá věc. Fakt, že žáci s učitelkou komunikují, slouží jako evidence vlastní úspěšnosti učitelky a je zdrojem uspokojení a př́ijemných emocí („dobrý pocit, vždycky potěši“). Naopak situace, kdy žáci neodpovídají na otázky, zůstávají i přes apely vyučujících zticha, je vnímána jako velmi nepříjemná.

Co je důležité, učitelky si cení toho, když se zapojuje třída jeho celek, nejen několik komunikativních žáků. Beata to komentuje: „Když pracují všichni, tak to považuju za povedenou hodinu. Když jsou na mě napojení. Když to vidím, že se na mě dívají, odpovídají, hlásí se i ti, co se třeba často nehlásí, tak to je určitě povedená hodina." Opět vidíme, že komunikace je indikátorem toho, zda u žáků probíhá učení. Za obzvláštní úspěch je považováno, když se do komunikace podaří zapojit i méně komunikativní žáky, kteří jsou tím pádem rovněž intenzivněji vtaženi do učení. Důraz na to, že by participovat měli všichni, je společný všem učitelkám, stejně jako povzdech, že se to nedaří a že mezi žáky jsou v tomto ohledu velké rozdíly. Jak říká Daniela: „Nevýhoda je, že mluví pořád ti stejní, což teda sleduju u sebe $v$ hodinách. Že bych se skutečně chtěla soustředit na to, aby se do té diskuse zapojilo víc lidí. Jasně, že je to daný tou strukturou třídy a tím, jak kdo chce nebo nechce mluvit.“

$\checkmark$ rozhovorech s učitelkami jsme se soustředili na to, abychom od nich získali popisy všech fokálních žáků. Na základě jejich pečlivé analýzy můžeme říci, že existuje pozoruhodná shoda mezi tím, jak se popisují sami žáci a jak je popisují jejich učitelky. Není překvapivé, že učitelky přesně rozpoznávají míru úspěšnosti žáků a také míru jejich participace. To jsou vnějškově zřetelné znaky, jimž navíc vyučující nutně musí věnovat pozornost (známkují žáky, vyvolávají je a hovoří s nimi). Zajímavější je to, že také odpovídajícím zpưsobem odhadují psychologické a osobnostní charakteristiky žáků. Uvedli jsme, že žáci rozřazení do jednotlivých skupin podle 
86 úspěšnosti a vokálnosti, vykazují určité společné charakteristiky. Lapidárně řečeno, jejich učitelky jsou s to tyto jejich charakteristiky „přečíst“.

Vokální úspěšné žáky popisují učitelky jako inteligentní a schopné. Zároveň o nich prohlašují, že jsou veselí, temperamentní a rychlí. Daniela říká o Ditě: „Dita, ta je šikovná, motivovaná, připravuje se a patři rozhodně k těm lepším. Je taková, že chce, ráda si popovídá, ráda řekne svůj názor, zasměje se, jo, je taková jako veselá. “V uvedené citaci je vokálnost spojována s veselostí, s optimistickou povahou své nositelky. Tato veselost se pojí s potřebou sdílení, která podle učitelek není komplikovaná žádnými zábranami - vokální úspěšní žáci se snadno a pohotově vyjadřují, ačkoli jejich rychlost někdy vede k určitým nedokonalostem. Aneta o Anně hovoří takto: „Anna, ta je šikovná, je hodně, hodně komunikativní, i se umí dobře vyjadřovat, si myslím. Je taková hodně temperamentní a umí reagovat pohotově... Je taková zbrklejší a naseká víc chyb kvưli tomu. “ Chybné výkony vokálních úspěšných nejsou učitelkami posuzovány př́liš př́sně (vokální úspěšní jsou nejtypičtěji nálepkováni jako „šikovni““ - viz obě citace výše), zdá se, že je prričítají četnosti a jisté překotnosti jejich vstupů do komunikace. Dalšími společnými vlastnostmi, které učitelky těmto žákům připisují, jsou sebevědomí a ambicióznost. Chantal popisuje Claudii následovně: „Ona je docela sebevědomá... I doma ji vedou k tomu, že je dobrá a že musí být nejlepší. A ona tak o sobě i smýšlí. “ Sebevědomí těchto žáků a jejich touha mít dobré výsledky jsou podle učitelek dalším motorem, který pohání jejich zapojení do komunikace.

Tiší úspěšní žáci jsou vnímáni jako inteligentní a přemýšliví. Podle učitelek jsou pomalí, ale precizní. Učitelky dále udávají, že jsou tito žáci silně introvertní a nejistí v kolektivu vrstevníků, což jim brání v zapojení do komunikace. Beata se vyjadřuje o Blance následovně:

Blanka, ta je tam nejlepší v té třídě. Ta je perfektní. Má všechny věci promyšlené správně, chápe perfektně. Nejen, že umí pravopis, umí i skladbu, takže to znamená, že fakt přemýšlí. Ale odpoví, jen když je donucena. Když není zbytí a dívám se na ni zoufale, tak ona odpoví... A když už se na ni podívám, tak pak řekne, ale ona vždycky i zrudne, takže si myslím, že prostě je taková introvertní, takže prostě takové osobnostní předpoklady jí brání.

Schopnosti tichých úspěšných tedy nejsou vnímány pouze jako kvalitní, jako $\checkmark$ př́padě vokálních úspěšných, nýbrž jako mimořádné. Pomalost těchto žáků není hodnocena negativně, podle učitelek jde o průvodní znak hlubokého přemýšlení, které u rychle reagujících vokálních úspěšných absentuje. Učitelky popisují zvláštní pouto mezi nimi a těmito žáky. Ti př́liš nekomunikují se svými spolužáky, jak ř́ká Daniela o Davidovi: „Ve tř́dě spiš existuje tak jako ve vlastní bublině... Je chytřejší než ostatní." S učitelkou však jsou ochotni interakci navázat, pokud je $k$ tomu silně vybízí. $V$ rozhovorech s tichými úspěšnými žáky jsme odhalili, že tito žáci věří, že učitelé vědí o jejich schopnostech (viz výše). Data od učitelek to potvrzují. Napríklad Aneta uvádí o Aleně: „Já když už vidím, že fakt nikdo neví, tak si říkám, že ta Alenka by to mohla vědět. Takže se na ni vždycky tak jako obrátím a ona to $v$ devadesáti procentech prostě jako ví.“ 
Také vokální neúspěšní žáci jsou učitelkami popisováni ve shodě s jejich vlastní sebedefinicí. To znamená jako silně komunikativní a temperamentní žáci, kteři usilují o pozornost ostatních a o dominanci v kolektivu. Aneta říká o Arnoštovi: „On je temperamentní, takový impulzivní trošku, bych řekla, i živější člověk celkově, takže prostě on je jak střela někdy, takže občas něco plácne, což jako zpưsobuje, že tam je proto veselo v té třídě.“ Chantal o Cesarovi: „On je hodně dominantní... On je celebrita naší školy... Všichni k němu vzhlíží. A samozřejmě jemu to dělá dobře, roste mu tím sebevědomí a on se tak prezentuje. Takže on je tady jakoby král... a on co řekne, tak to všichni jsou z toho hotoví, a tím narušuje tu hodinu. “ Z citace vysvítá, že skutečnost, že na sebe tito žáci stahují pozornost svých spolužáků, je do jisté míry vnímána jako rušivý element. Vokální neúspěšní žáci jsou těmi, kteří hovoří často, avšak ne vždy učitelky jejich příspěvky pozitivně kvitují. Zároveň však v jejich výpovědích zřídka zazní přímý odsudek komunikační rozpínavosti těchto žáků. Lze říci, že byt' učitelky jejich chování považují místy za obtěžující, jsou vưči nim značně shovívavé. Aneta glosuje potíže s Arnoštovou nadměrnou vokálností takto:

V šestce a v sedmičce to některým klukům vadilo, i rodiče říkali, že jim vadí, že prostě Arnošt vyrušuje. Ale já jsem jim potom řekla: „Děcka, prostě to tak berte, protože já bych ho takhle musela napomínat celou hodinu. "Někdy ho napomenu jednou dvakrát a někdy si dá fakt říct a je ticho. Ale z toho on potřebuje být středem té pozornosti a oni to ř́kají i ti kluci, kteří to vědí. Tak oni ho prostě berou takovýho, jakej je.

Vidíme, že učitelka je nejen smířená s Arnoštovou tendencí vyrušovat, ale dokonce intervenuje u jeho spolužáků, aby daný stav rovněž akceptovali. Upovídanost vokálních neúspěšných žáků se podle učitelek neuplatňuje ve všech situacích stejně silně. Učitelky udávají (opět ve shodě se žákovskými proklamacemi), že se tito žáci zapojují především tehdy, nejde-li o faktické znalosti, nýbrž o prezentování vlastních názorů, a že mají tendenci dopouštět se chyb. Beata Bohumilovy výkony komentuje takto:

Bohumil se zapojí spiš tam, kde se dá debatovat, kde se dá přemýšlet, kde ta odpověd' není jednoznačná, kde ji musí vymyslet... On umí okecat, takže na to spoléhá, že to nějak jako řekne, ale on tam má chyby. Takže my jsme ted’ brali věty jednoduché minulou hodinu, to se taky několikrát hlásil a neměl to vždycky dobře. On dělá chyby.

Pozoruhodné je, že učitelky přes časté chybné výkony těchto žáků rovněž souhlasí, že mají vyšší potenciál, než odpovídá jejich výsledkům. Stejně tak zcela koresponduje jejich vysvětlení, totiž malé úsilí a malá domácí příprava vokálních neúspěšných žáků. Daniela hodnotí Dalibora: „On má na to mít lepší výsledky. Určitě. Jemu to prostě jenom takhle stačí. “ Claudia o Cesarovi: „On na to prostě kašle. Ale myslím, že kdyby se učil a pracoval, tak má jedničky, dvojky bez problémů.“

Poslední sledovanou skupinou byli tiší neúspěšní. Ti jsou učitelkami ličeni jako zakřiknutí až úzkostní žáci, kteří nemluví, protože se obávají, že jejich výkon bude chybný. Daniela říká o Denisovi: „On je takovej tišší kluk, že i jako mluví potišeji, stydí se, takovej zakřiknutej... Bere si slovo málokdy... Má pocit, že ty jeho promluvy 
88 nebudou stát za moc. “ V této citaci učitelka reflektuje nejen Denisovo chování, ale též odhaduje jeho prričiny, které přitom v samotné komunikaci nejsou zjevné („má pocit, že ty jeho promluvy nebudou stát za moc“). Tato atribuce je mezi učitelkami sdílená. Aneta na otázku, proč Andrea v hodinách nemluví, odpovídá: „Myslí si, že to řekne špatně. " Rovněž mezi učitelkami panuje naprostá shoda v tom, že tito žáci jsou bez talentu a jejich kognitivní schopnosti jsou velmi limitované. Daniela o Denisovi uvádí: „Denis, ten to má, jako že si myslím, že fakt si to nepamatuje, nebo nechápe, no. U něho je to takový, že se mu to fakt asi do té hlavy špatně skládá.“ Slabé kognitivní schopnosti jsou učitelkami vnímány jako vrozené a $v$ zásadě neovlivnitelné. Chantal o Cyrilovi: „Asi je to nepedagogické, ale neočekávám, že mně diktát napíše na jedničku nebo na dvojku, protože vím, na co má a na co nemá... Asi to nemá v genech. " V citaci vidíme, že Chantal nejen vysvětluje minulé Cyrilovy výkony, ale vytváří očekávání do budoucna. 0 tichých neúspěšných žácích totiž učitelky předpokládají, že se nemohou př́liš zlepšit, bez ohledu na úsilí, které do věci vloží. Chantal Cyrilův přistup ke zvládání školních povinností dále komentuje: „Zas já vím, že on se snaží. Že když má pětky z diktátu, tak se mi naučí do literatury a nechá se vyvolat. Což dělá sám a jako jediný se nechává vyvolat z literatury. "Podobně Beata ř́ká o Barboře:

Překvapivě na konci osmičky a na začátku devítky se tak nějak zmátořila, že byla i chvilku na trojkách, což jsem považovala za velký úspěch. Ona na ty trojky dře, neskutečně maká, jenže ona často selhává, má špatnou výbavu pojmů, velmi slabou slovní zásobu... Ona má jako fakt slabší intelekt.

V tomto ohledu jsou tiší neúspěšní vnímáni jako protiklad vokálních neúspěšných - ti se nesnaží, ale mají potenciál, v jejich prípadě učitelé vidí prostor $k$ zlepšení. Tiší neúspěšní, i pokud přikročí k žádoucím a oceňovaným aktivitám („,nechají se vyvolat, dřou“), nejvýše krátkodobě překvapí („,překvapivě se zmátořila“), avšak jejich pozice se $v$ očích učitelek nemění.

Zde prezentovaná analýza výroků učitelek o fokálních žácích ukazuje, že učitelky přičítají žákům různé vlastnosti, které podle nich podmiňují způsob jejich zapojení do komunikace. Výše jsme uvedli, že rozdíly v četnosti participace jednotlivých žáků vnímají negativně a přály by si, aby s nimi rovnoměrně hovořili všichni žáci. Pokud však podrobíme detailnějšímu rozboru jejich výroky o tom, jak žáky vyvolávají, zjistíme, že spiše vycházejí vstříc žákovským participačním tendencím, než že by se je pokoušely nějak reformovat. Dưvodem je přitom snaha učitelek, aby se všichni ve tř́ídě cítili dobře. Velmi přesně to vyjadřuje Chantal:

Snažím se vyvolávat toho, kdo se hlásí, aby byl oceněn, že projeví tu aktivitu. Když už se teda někdo přihlásí a nevyvolat ho, to by bylo takové nefér. Ale samozřejmě, když se mně někdo hlásí pětkrát po sobě, tak ho nevyvolám. Většinou chci, aby se to prostřídalo. Ale třeba u některých lidí, konkrétně u toho Cyrila, tak třeba když vidím, že nemají vyplněné v sešitě, tak je schválně nevyvolám, protože vím, že jim to není úplně př́ijemné. 
Ačkoli učitelky v rưzné míře deklarují tendenci vyvolávat i tiché žáky (nejvíce to platí pro Danielu), obecný vzorec je takový, jak popisuje Chantal. Učitelky chtějí, aby s nimi žáci komunikovali, proto odměňují jejich iniciativnost tím, že vokálním dávají a ponechávají slovo. Tím se vokálnost těchto žáků posiluje. Na tiché úspěšné se, jak jsme doložili výše, adresně obracejí v momentě, kdy pokládají složitou otázku, čímž upevňují jejich pozici mimořádných žáků. Tiší neúspěšní jsou z komunikace vylučováni, avšak učitelé jsou přitom vedeni dobrým úmyslem ochránit je před veřejným selháním. Pokud se na ně obracejí, tak s jednoduchými dotazy. Aneta ř́ká, že je vyvolává, když ví, „že to nemůžou zblbnout. Aby si nepřipadali blbě, hloupě.“

Ve výsledku nejdou učitelky proti žákovským záměrům a preferencím. Vokální žáci chtějí hovořit co nejvíce. Tiší úspěšní chtějí hovořit jen v exkluzivních situacích, kdy pravděpodobně podají nadstandardní výkon. Tiší neúspěšní nechtějí hovořit vưbec. Všichni dostávají, co chtějí.

\section{Diskuse a závěr}

Cílem této studie bylo zachytit významy, které jsou participaci připisovány ze strany žáků i jejich učitelek. Zajímalo nás, jak se mezi sebou v tomto ohledu liší žáci vokální a tiší a žáci s dobrým a slabým prospěchem. Sledovali jsme čtyři rưzné skupiny žáků, základní charakteristiky, které jsme u nich identifikovali, shrnujeme v tabulce 2 .

Tabulka 2 Porovnání žákovských skupin

\begin{tabular}{|c|c|c|c|c|c|}
\hline & $\begin{array}{l}\text { Hodnocení } \\
\text { vlastního } \\
\text { potenciálu }\end{array}$ & $\begin{array}{l}\text { Hodnocení } \\
\text { vlastního } \\
\text { úsilí }\end{array}$ & $\begin{array}{l}\text { Obavy } \\
\text { z komunikace }\end{array}$ & $\begin{array}{l}\text { Spontánní } \\
\text { zapojování se } \\
\text { do komunikace }\end{array}$ & $\begin{array}{l}\text { Obvyklá reakce } \\
\text { na vyvolání } \\
\text { učitelem }\end{array}$ \\
\hline Vokální úspěšní & vysoké & vysoké & ne & ano & nadšená \\
\hline Tiší úspěšní & vysoké & vysoké & ano & ne & vstř̌icná \\
\hline $\begin{array}{l}\text { Vokální } \\
\text { neúspěšní }\end{array}$ & vysoké & nízké & ne & ano & nadšená \\
\hline Tiší neúspěšní & nízké & vysoké & ano & ne & negativní \\
\hline
\end{tabular}

V odborné literatuře $\mathrm{k}$ našemu tématu se opakovaně konstatuje, že participační intence žáků jsou silně formovány jejich vyhlídkou na úspěch či očekáváním neúspěchu. Clarková (2015) dodává, že žáci pojímají znalosti jako klíčový předpoklad vstupu do výukové komunikace. Naše analýza s tímto konvenuje, avšak identifikuje též situace, kdy znalosti nejsou vnímány jako nutné pro dosažení úspěchu. Jde o diskusní sekvence, v nichž žáci mohou volně prezentovat své názory. $V$ takovýchto okamžicích se zapojují rovněž ti, kteří nedisponují obsáhlými znalostmi, ale cení si své pohotovosti a komunikační obratnosti. Opakem vyhlídky na úspěch je předpoklad neúspěchu, který vede žáky $\mathrm{k}$ záměru setrvat $v$ komunikační nečinnosti. Tvrzení, že 
90 se žáci nezapojují kvůli obavám, že by mohla být odhalena jejich neznalost či neschopnost, bylo v literatuře formulováno opakovaně (např. Hall et al., 2010; Clarke, 2015; Snell \& Lefstein, 2018). Naše analýza to potvrzuje, avšak dodává, že obavy z neúspěchu mají poněkud fantomový charakter. Nezdá se totiž, že by si někdo ze žáků vysloužil nálepku neschopného a hloupého kvưli svým neadekvátním a chybným př́spěvkům do komunikace. Naopak, tato nálepka je připisována spiše žákům, kteří mlčí a nezapojují se.

Ačkoli jsou tendence vyhnout se úspěchu a podat úspěšný výkon do jisté míry univerzální, naše analýza jasně ukazuje, že se od sebe jednotlivé skupiny sledovaných žáků $v$ tomto ohledu značně liší. Zde nám může pomoci prohloubit naši interpretaci teorie školní výkonové motivace žáků (Hrabal \& Pavelková, 2010, 2011). Tito autoři rozlišují čtyři typy žáků podle toho, jaká je jejich školní výkonová motivace: Typ 1 má vysokou potřebu úspěšného výkonu a současně nízkou potřebu vyhnutí se neúspěchu. Typ 2 má nízkou potřebu úspěšného výkonu a zároveň vysokou potřebu vyhnutí se neúspěchu. Typ 3 má vysokou potřebu úspěšného výkonu a současně vysokou potřebu vyhnutí se neúspěchu. Typ 4 má nízkou potřebu úspěšného výkonu a k tomu nízkou potřebu vyhnutí se neúspěchu. Domníváme se, že typy identifikované Hrabalem a Pavelkovou (tamtéž) korespondují s námi sledovanými skupinami fokálních žáků. Typu 1 odpovídají vokální úspěšní žáci, kteři věři ve své schopnosti, jsou silně motivováni participovat vyhlídkou na jejich úspěšné uplatnění a jen málo inhibováni obavami z neúspěchu. Typu 2 odpovídají tiší neúspěšní žáci, kteří neusilují o úspěch, nebot' nevěří, že by jej mohli dosáhnout, a zároveň jsou silně brzděni obavami z neúspěchu. Typu 3 odpovídají tiší úspěšní žáci, kteří si přejí podat úspěšný výkon, ale potřebují si být maximálně jistí, že neselžou. Pokud tuto jistotu nemají, participaci se vyhnou. Konečně typu 4 odpovídají vokální neúspěšní žáci, kteří jsou ochotni participovat, aniž by nutně očekávali úspěch, přičemž možnost neúspěchu je príliš neodrazuje.

Cílem této studie bylo ověrit, že ve třídě existují skupiny žáků s podobnými participačními vzorci podloženými určitými sdílenými tendencemi v jejich subjektivním vnímání a prožívání. $V$ textu detailně popisujeme, jak sami sebe vidí členové jednotlivých sledovaných skupin a jak zdůvodňují své komunikační chování. Co bychom rádi podtrhli na tomto místě, je skutečnost, že vůbec existuje konzistence uvnitř jednotlivých skupin a rozdíly oproti skupinám ostatním. Jinými slovy, naše nálezy dokládají silný vztah mezi participačním chováním a identitou. $V$ tomto naše nálezy konvenují s tezemi Kumpulainenové a Rajaly (2017), kteří (za pomoci jiného typu dat i analýzy) ukazují, že jestliže se změní zpưsob zapojení jedince do komunikace, promění se také jeho identita. Podobně nepochybně platí, že promění-li se identita žáka, dojde také $\mathrm{k}$ posunům $v$ participaci. Jde zkrátka o spojené nádoby.

Participační chování je médium, skrze které žáci sdělují a sdílejí své představy o sobě samých. Pokud by tomu tak nebylo, bylo by jen stěží vysvětlitelné, jak je možné, že učitelky popisují žáky $v$ jednotlivých skupinách velmi podobně, jako se popisují oni sami. Goffman (1967) ve svém klasickém díle zabývajícím se interakčním chováním vysvětluje, že v běžné interakci každý jednotlivec rozvíjí a udržuje určitou tvář („face“), vzorec verbálních a neverbálních akcí směřujících k vyjádření 
vlastních atributů. Co se týče volby tváře, má jednotlivec jen malou volnost, spíše vybírá z v daném společenství předdefinovaných typů. Tato teoretická perspektiva dobře odpovídá našemu popisu. Žáci se chovají určitým schematickým způsobem a zároveň jsou určitým schematickým způsobem čteny jejich charakteristiky. Podle Meada (2017) se identita ustavuje tak, že jedinec přebírá pohled druhých na sebe sama. Goffman (1967) považuje toto pojetí za zjednodušené. Spíše se podle něj jedinec musí spoléhat na ostatní, že mu pomohou zkompletovat obraz jeho osobnosti, z nějž je mu samotnému dovoleno nakreslit jen určitou část.

Na základě našich dat můžeme Goffmanovy teze konkretizovat například následovně. Prostřednictvím hovornosti žáci inscenují svoji veselost a temperamentnost, prostřednictvím zamlklosti svoji ostýchavost a zádumčivost. Co je ale z pedagogického hlediska mimořádně významné a zajímavé, inscenují rovněž svoje nadání a schopnosti. Ve výpovědích učitelek (viz kapitola 5.3) nelze přehlédnout určitou hierarchii: 1) tiší úspěšní jsou vnímáni jako mimořádní, 2) vokální úspěšní jako velmi schopní, 3) vokální neúspěšní jako vcelku schopní, 4) tiší neúspěšní jako neschopní. Interpretovat logiku tohoto rozložení není snadné, především proto, že oba krajní póly jsou obsazeny žáky s nízkou mírou komunikativnosti. Dovolíme si tedy jen provizorní pokus, přičemž budeme vycházet z premisy, že učitelé si tvoří úsudky o žácích tak, že je porovnávají mezi sebou (Drexlerová, 2018). Vysvětlit, proč jsou vokální úspěšní vnímáni jako nadanější než vokální a tiší neúspěšní, je snadné. Mají lepší známky, podávají lepší výkony. Dále víme, že vokální neúspěšní jsou vnímáni jako nadanější nežli tiší neúspěšní. Zde se domníváme, že dochází k jejich zvýhodnění díky vysoké participaci. Skrze tuto participaci se jim totiž daří inscenovat nejenom snahu (učitelé o nich sice vědí, že se doma neučí, ale vidí, jak se snaží přímo ve vyučování), ale hlavně potenciál. Učitelé totiž se žáky sdílejí předpoklad, že komunikaci se vyhýbá ten, kdo nic neumí. Jistou záhadou zůstává primát tichých úspěšných. Domníváme se, že jejich strategií je spoléhání na dưvěrný vztah s učiteli, kterým v jistém smyslu lichotí, že si je tito žáci zvolili jako výhradní komunikační partnery. Navíc tito žáci očividně vybočují z folklorního rčení, že mlčí ten, kdo nic neumí. Tato komunikační mimořádnost patrně vede $\mathrm{k}$ tomu, že u nich učitelé mají tendenci vnímat mimořádnost též v oblasti kognitivní.

Rozčlenění žáků podle percipovaného nadání má své masivní důsledky. Jak jsme uvedli s odkazem na Meada (2017) a Goffmana (1967) výše, signifikantní druzí, jimiž učitelky bez pochyby jsou, spoludefinují žákovu identitu. Snellová a Lefstein (2018) uvádějí, že to, jak žák vnímá své schopnosti, je ovlivněno očekáváními a úsudkem učitele. Mezi žáky se vytváří kompetitivní kultura a implicitní žebříček schopností. Žáci, kteři v důsledku předchozího sami sebe vnímají jako méně schopné, mají tendenci vzdávat složitější úkoly (Snell \& Lefstein, 2018). Vytváří se sebeposilující cyklus: protože se žák vnímá jako málo schopný, omezuje svoji participaci, v důsledku toho ho vnímá jako málo schopného též učitel a subtilně k němu vysílá tuto zprávu, což vede $k$ tomu, že se žák ještě více stáhne.

Tím se dostáváme k tématu vzdělávacích nerovností, jímž jsme tuto studii otevřeli. Asymetrie v participaci je totiž asymetrií v příležitostech k učení (Howe \& Abedin, 
92 2013). Tiší neúspěšní žáci jsou jednoznačně znevýhodněnou a ohroženou skupinou. Tato studie přitom ukázala, že se do této pozice nedostávají vinou zlé vưle svých vyučujících. Naopak, učitelky se je snaží chránit a jednají v dobré víře. Nezamýšlené důsledky akcí a interakcí všech aktérů však způsobují jejich marginalizaci. Naopak pro ostatní tř̌ sledované skupiny jsou jejich participační vzorce v zásadě výhodné. Vokální úspěšní žáci hovoří velmi často, díky čemuž se podle vlastních slov hodně naučí. Vokální neúspěšní žáci hovoří dokonce absolutně nejčastěji ze všech (viz Švaříček et al., v př́ipravě), navíc se jim daří získávat od učitelek korektivní zpětnou vazbu, což je ve vztahu $k$ učení velkým přínosem. Tiší úspěšní žáci sice hovoří méně často, avšak výhradně v situacích, které jsou kognitivně náročné a představují možnost akcelerace učení.

Nevíme, zda jsou tiší neúspěšní ve třídě jedinou znevýhodněnou skupinou. Naše analýza totiž nijak nevypovídá o žácích, kteři jsou průměrní z hlediska míry participace a/nebo prospěchu. Prozkoumání pozice těchto žáků zůstává výzvou do budoucna.

\section{Literatura}

Alexander, R. (2006). Towards dialogic teaching: Rethinking classroom talk. Cambridge: Dialogos.

Alexander, R. (2018). Developing dialogic teaching: Genesis, process, trial. Research Papers in Education, 33(5), 561-598.

Applebee, A. N., Langer, J., Nystrand, M., \& Gamoran, A. (2003). Discussion-based approaches to developing understanding: Classroom instruction and student performance in middle and high school english. American Educational Research Journal, 40(3), 685-730.

Black, L. (2004). Differential participation in whole-class discussions and the construction of marginalised identities. Journal of Educational Enquiry, 5(1), 34-54.

Black, L. (2007). Analysing cultural models in socio-cultural discourse analysis. International Journal of Educational Research, 46(1-2), 20-30.

Brophy, J. E., \& Good, T. L. (1970). Teachers' communication of differential expectations for children's classroom performance: Some behavioral data. Journal of Educational Psychology, 61(5), 365-374.

Brown, B. (2004). Discursive identity: Assimilation into the culture of science classroom and its implications for minority students. Journal of Research in Science Teaching, 41(8), 810-834.

Clarke, S. N. (2015). The right to speak. In L. B. Resnick, Ch. S. C. Asterhan, \& S. N. Clarke (Eds.), Socializing intelligence through academic talk and dialogue (s. 167-180). Washington: AERA.

Clarke, S. N., Howley, I., Resnick, L., \& Rosé, C. P. (2016). Student agency to participate in dialogic science discussions. Learning, Culture and Social Interaction, 10, 27-39.

Drexlerová, A. (2018). Kluků je škoda, holky na to nemají: Genderové aspekty v hodnocení nejslabších žákư třídy. Studia paedagogica, 23(1), 9-28.

Goffman, E. (1967). Interaction ritual: Essays on face-to-face behavior. New York: Anchor Books.

Hall, L. A., Johnson, A. S., Juzwik, M. M., Wortham, S. E., \& Mosley, M. (2010). Teacher identity in the context of literacy teaching: Three explorations of classroom positioning and interaction in secondary schools. Teaching and Teacher Education, 26(2), 234-243.

Helgevold, N. (2016). Teaching as creating space for participation - establishing a learning community in diverse classrooms. Teachers and Teaching, 22(3), 315-328. 
Howe, Ch., \& Abedin, M. (2013). Classroom dialogue: A systematic review accross four decades of research. Cambridge Journal of Education, 43(3), 325-356.

Hrabal, V., \& Pavelková, I. (2010). Jaký jsem učitel. Praha: Portál.

Hrabal, V., \& Pavelková, I. (2011). Školní výkonová motivace žáků: Dotazník pro žáky. Praha: Národní ústav odborného vzdělávání.

Ing, M., Webb, N. M., Franke, M. L., Turrou, A. C., Wong, J., Shin, N., \& Fernandez, C. H. (2015). Student participation in elementary mathematics classrooms: The missing link between teacher practices and student achievement? Educational Studies in Mathematics, 90(3), 341-356.

Jurik, V., Gröschner, A., \& Seidel, T. (2013). How student characteristics affect girls' and boys' verbal engagement in physics instruction. Learning and Instruction, 23(1), 33-42. http:// dx.doi.org/10.1016/j.learninstruc.2012.09.002.

Kelly, S. (2008). Race, social class, and student engagement in middle school English classrooms. Social Science Research, 37(2), 434-448.

Kovalainen, M., \& Kumpulainen, K. (2007). The social construction of participation in an elementary classroom community. International Journal of Educational Research, 46(3-4), 141-158.

Kumpulainen, K., \& Rajala, A. (2017). Dialogic teaching and students' discursive identity negotiation in the learning of science. Learning and Instruction, 48, 23-31.

Lefstein, A., \& Snell J. (2014). Better than best practice: Developing teaching and learning through dialogue. London: Routledge.

Mead, G. H. (2017). Mysl, já a společnost. Praha: Portál.

Mercer, N., \& Littleton, K. (2007). Dialogue and the development of children's thinking: A sociocultural approach. London: Routledge.

Muhonen, H., Pakarinen, E., Poikkeus, A.-M., Lerkkanen, M.-K., \& Rasku-Puttonen, H. (2018). Quality of educational dialogue and association with students' academic performance. Learning and Instruction, 55, 67-79.

Myhill, D. (2002). Bad boys and good girls? Patterns of interaction and response in whole class teaching. British Educational Research Journal, 28(3), 339-352.

O'Connor, C., Michaels, S., \& Chapin, S. (2015). „Scalling down“ to explore the role of talk in learning: From disctrict intervention to controlled classroom study. In L. B. Resnick, Ch. S. C. Asterhan, \& S. N. Clarke (Eds.), Socializing intelligence through academic talk and dialogue (s. 111-126). Washington: AERA.

Resnick, L. B., Asterhan, Ch. S. C., \& Clarke, S. N. (2017). Student discourse for learning. In G. E. Hall, D. M. Gollnick, \& L. F. Qzinn (Eds.). Handbook of teaching and learning. Wiley: Wiley-Blackwell.

Sedova, K., Sedlacek, M., Svaricek, R., Majcik, M., Navratilova, A., Drexlerova, A., Kychler, J., \& Salamounova, Z. (2019). Do those who talk more learn more? The relationship between student classroom talk and student achievement. Learning and Instruction, 63, 101217, https://doi.org/10.1016/j.learninstruc.2019.101217.

Seidel, T. (2006). The role of student characteristics in studying micro teaching-learning environments. Learning Environments Research, 9, 253-271. http://dx.doi.org/10.1007/ s10984-006-9012-x.

Snell, J., \& Lefstein, A. (2018). „Low ability“, participation, and identity in dialogic pedagogy. American Educational Research Journal, 55(1), 40-78.

Šed’ová, K. (2016). Co je dialogické vyučování. In K. Šed’ová, R. Švaříček, M. Sedláček, \& Z. Šalamounová, Jak se učitelé učí. Cestou profesního rozvoje k dialogickému vyučování (s. 11-64). Brno: MU.

Šed’ová, K., Sucháček, P., \& Majcík, M. (2015). Kdopak to mluví? Participace žáků ve výukové komunikaci na druhém stupni základní školy. Pedagogika, 65(2), 143-162.

Šed’ová, K., \& Šalamounová, Z. (2016). Teacher expectancies, teacher behaviour and students'participation in classroom discourse. Journal of Educational Enquiry, 15(1), 44-61.

Šed’ová, K., Švařičck, R., \& Šalamounová, Z. (2012). Komunikace ve školní třídě. Praha: Portál. 
94 Triplett, Ch. F. (2007). The social construction of „struggle“: Influences of school literacy contexts, curriculum, and relationships. Journal of Literacy Research, 39(1), 95-126.

Webb, N. M., Franke, M. L., Ing, M., Wong, J., Fernandez, C. H., Shin, N., \& Turrou, A. C. (2014). Engaging with others' mathematical ideas: Interrelationships among student participation, teachers instructional practices, and learning. International Journal of Educational Research, 63(1), 79-93.

Zormanová, L. (2009). Gender ve vzdělávání dětí a mládeže na ZŠ: srovnání míry aktivity chlapců a dívek ve výuce občanské výchovy na základní škole (Disertační práce). Brno: PedF MU. Dostupné z http: / / is.muni.cz/th/239706/pedf_d/

doc. Mgr. Klára Šed’ová, Ph.D.

Ústav pedagogických věd

Filozofická fakulta, Masarykova univerzita

Arna Nováka 1, 60200 Brno

ksedova@phil.muni.cz 